A11 100993601

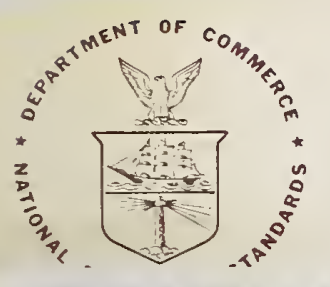

NBS TECHNICAL NOTE 1028

NAT'L INST. OF STAND \& TECH

||||||||

||||||||||||||||||||||||||||||||||||||||||||||||

Al1107 241958

U.S. DEPARTMENT OF COMMERCE / National Bureau of Standards

\title{
Theoretical and Experimental Investigations of
}

Electromagnetic Field Distortion Due to a Perfectly Conducting Rectangular Cylinder in a

Transverse Electromagnetic Cell

$Q C$
100
05753
No.1028
1981
$C .2$




\section{NATIONAL BUREAU OF STANDARDS}

The National Bureau of Standards' was established by an act of Congress on March 3, 1901. The Bureau's overall goal is to strengthen and advance the Nation's science and technology and facilitate their effective application for public benefit. To this end, the Bureau conducts research and provides: (1) a basis for the Nation's physical measurement system, (2) scientific and technological services for industry and government, (3) a technical basis tor equity in trade, and (4) technical services to promote public safety. The Bureau's technical work is performed by the National Measurement Laboratory, the National Engineering Laboratory, and the Institute for Computer Sciences and Technology.

THE NATIONAL MEASUREMENT LABORATORY provides the national system of physical and chemical and materials measurement; coordinates the system with measurement systems of other nations and furnishes essential services leading to accurate and uniform physical and chemical measurement throughout the Nation's scientific community, industry, and commerce; conducts materials research leading to improved methods of measurement, standards, and data on the properties of materials needed by industry, commerce, educational institutions, and Government; provides advisory and research services to other Government agencies; develops, produces, and distributes Standard Reference Materials; and provides calibration services. The Laboratory consists of the following centers:

Absolute Physical Quantities ${ }^{2}$ - Radiation Research - Thermodynamics and Molecular Science - Analytical Chemistry - Materials Science.

THE NATIONAL ENGINEERING LABORATORY provides technology and technical services to the public and private sectors to address national needs and to solve national problems; conducts research in engineering and applied science in support of these efforts; builds and maintains competence in the necessary disciplines required to carry out this research and technical service; develops engineering data and measurement capabilities; provides engineering measurement traceability services; develops test methods and proposes engineering standards and code changes; develops and proposes new engineering practices: and develops and improves mechanisms to transfer results of its research to the ultimate user. The Laboratory consists of the following centers:

Applied Mathematics - Electronics and Electrical Engineering ${ }^{2}$ - Mechanical Engineering and Process Technology $y^{2}$ - Building Technology - Fire Research Consumer Product Technology - Field Methods.

THE INSTITUTE FOR COMPUTER SCIENCES AND TECHNOLOGY conducts research and provides scientific and technical services to aid Federal agencies in the selection, acquisition, application, and use of computer technology to improve effectiveness and economy in Government operations in accordance with Public Law 89-306 (40 U.S.C. 759), relevant Executive Orders, and other directives; carries out this mission by managing the Federal Information Processing Standards Program, developing Federal ADP standards guidelines, and managing Federal participation in ADP voluntary standardization activities; provides scientific and technological advisory services and assistance to Federal agencies; and provides the technical foundation for computer-related policies of the Federal Government. The Institute consists of the following centers:

Programming Science and Technology — Computer Systems Engineering.

'Headquarters and Laboratories at Gaithersburg, MD, unless otherwise noted; mailing address Washington, DC 20234.

${ }^{2}$ Some divisions within the center are located at Boulder, $\mathrm{CO} 80303$. 


\section{Theoretical and Experimental Investigations of Electromagnetic Field Distortion Due to a Perfectly Conducting Rectangular Cylinder in a Transverse Electromagnetic Cell \\ ¿ATORAL BUREAU OF ERANDARDE UIBEART JUN 151981}

Motohisa Kanda

Electromagnetic Fields Division

National Engineering Laboratory

National Bureau of Standards

Boulder, Colorado 80303

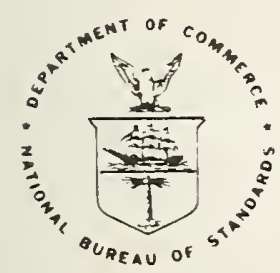

U.S. DEPARTMENT OF COMMERCE, Malcolm Baldrige, Secretary

NATIONAL BUREAU OF STANDARDS, Ernest Ambler, Director 
NATIONAL BUREAU OF STANDARDS TECHNICAL. NOTE 1028

Nat. Bur. Stand. (U.S.), Tech. Note 1028, 48 pages (April 1981)

CODEN: NBTNAE 


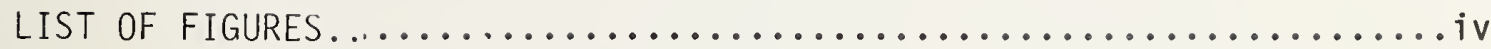

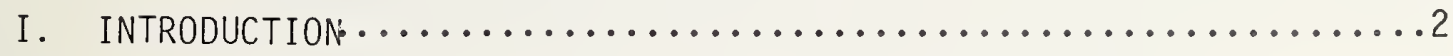

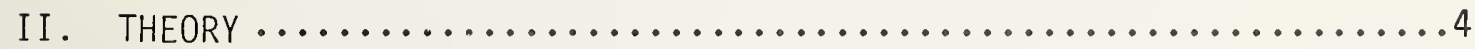

III. THEORETICAL AND EXPERIMENTAL RESULTS $\ldots \ldots \ldots \ldots \ldots \ldots \ldots$

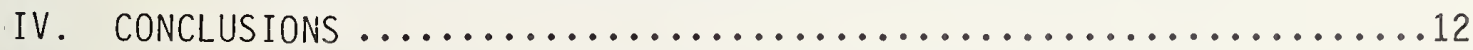

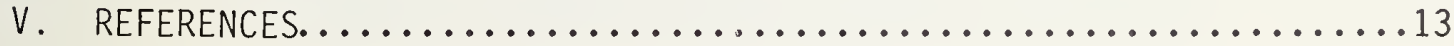




\section{LIST OF FIGURES}

Figure 1. Curve of equal $\mathrm{TE}_{01}$ and $\mathrm{TE}_{10}$ cutoff frequencies for a transverse electromagnetic cel1.................14

Figure 2. Normalized $\mathrm{TE}_{01}$ cutoff wavelength for a transverse

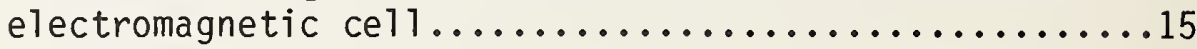

Figure 3. Electromagnetic field distortion due to a metallic cut in a transverse electromagnetic cell (electrostatic

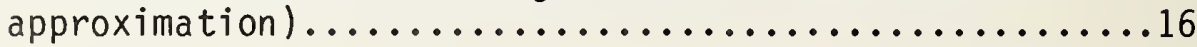

Figure 4. Coordinate system of a rectangular cylinder in a parallel plate waveguide........................

Figure 5. Magnetic field distortion due to a perfectly conducting cylinder (width $\ell=18 \mathrm{~cm}$, height $\mathrm{h}=5.5 \mathrm{~cm}$ ) in $a$ transverse electromagnetic cell at $1 \mathrm{MHz} . \ldots \ldots \ldots \ldots 18$

Figure 6. Magnetic field distortion due to a perfectly conducting cylinder (width $\ell=18 \mathrm{~cm}$, height $\mathrm{h}=5.5 \mathrm{~cm}$ ) in a transverse electromagnetic cell at $2 \mathrm{MHz} . . . \ldots \ldots \ldots . . .19$

Figure 7. Magnetic field distortion due to a perfectly conducting cylinder (width $\ell=18 \mathrm{~cm}$, height $\mathrm{h}=5.5 \mathrm{~cm}$ ) in a transverse electromagnetic cell at $5 \mathrm{MHz} . \ldots \ldots \ldots . . .20$

Figure 8. Magnetic field distortion due to a perfectly conducting cylinder (width $\ell=18 \mathrm{~cm}$, height $\mathrm{h}=5.5 \mathrm{~cm}$ ) in a transverse electromagnetic cell at $10 \mathrm{MHz} \ldots \ldots \ldots \ldots . .21$

Figure 9. Magnetic field distortion due to a perfectly conducting cylinder (width $\ell=18 \mathrm{~cm}$, height $\mathrm{h}=5.5 \mathrm{~cm}$ ) in a transverse electromagnetic cell at $50 \mathrm{MHz} . \ldots \ldots \ldots . . .22$

Figure 10. Magnetic field distortion due to a perfectly conducting cylinder (width $\ell=18 \mathrm{~cm}$, height $\mathrm{h}=5.5 \mathrm{~cm}$ ) in a transverse electromagnetic cell at $100 \mathrm{MHz} . \ldots . . . . .23$

Figure 11. Magnetic field distortion due to a perfectly conducting cylinder (width $\ell=18 \mathrm{~cm}$, height $\mathrm{h}=15 \mathrm{~cm}$ ) in a transverse electromagnetic cell at $2 \mathrm{MHz} . \ldots \ldots \ldots \ldots .24$

Figure 12. Magnetic field distortion due to a perfectly conducting cylinder (width $\ell=18 \mathrm{~cm}$, height $h=15 \mathrm{~cm}$ ) in a transverse electromagnetic cell at $5 \mathrm{MHz} \ldots \ldots \ldots \ldots \ldots 25$

Figure 13. Magnetic field distortion due to a perfectly conducting cylinder (width $\ell=18 \mathrm{~cm}$, height $\mathrm{h}=15 \mathrm{~cm}$ ) in a transverse electromagnetic cell at $10 \mathrm{MHz} . \ldots \ldots \ldots . .26$ 
Figure 14. Magnetic field distortion due to a perfectly conducting cylinder (width $\ell=18 \mathrm{~cm}$, height $\mathrm{h}=15 \mathrm{~cm}$ ) in a transverse electromagnetic cell at $50 \mathrm{MHz} . \ldots \ldots \ldots . . .27$

Figure 15. Magnetic field distortion due to a perfectly conducting cylinder (width $\ell=18 \mathrm{~cm}$, height $\mathrm{h}=15 \mathrm{~cm}$ ) in a transverse electromagnetic cell at $100 \mathrm{MHz} . \ldots . . . . .28$

Figure 16. Magnetic field distortion due to a perfectly conducting cylinder (width $\ell=18 \mathrm{~cm}$, height $\mathrm{h}=25 \mathrm{~cm}$ ) in a transverse electromagnetic cell at $2 \mathrm{MHz} . . . \ldots \ldots . . .29$

Figure 17. Magnetic field distortion due to a perfectly conducting cylinder (width $\ell=18 \mathrm{~cm}$, height $h=25 \mathrm{~cm}$ ) in a transverse electromagnetic cell at $5 \mathrm{MHz} . \ldots \ldots \ldots . . .30$

Figure 18. Magnetic field distortion due to a perfectly conducting cylinder (width $\ell=18 \mathrm{~cm}$, height $\mathrm{h}=25 \mathrm{~cm}$ ) in $a$ transverse electromagnetic cell at $10 \mathrm{MHz} \ldots \ldots \ldots \ldots . . .31$

Figure 19. Magnetic field distortion due to a perfectly conducting cylinder (width $\ell=18 \mathrm{~cm}$, height $\mathrm{h}=25 \mathrm{~cm}$ ) in a transverse electromagnetic cell at $50 \mathrm{MHz} \ldots \ldots \ldots \ldots . . .32$

Figure 20. Magnetic field distortion due to a perfectly conducting cylinder (width $\ell=18 \mathrm{~cm}$, height $\mathrm{h}=25 \mathrm{~cm}$ ) in a transverse electromagnetic cell at $100 \mathrm{MHz} . . . \ldots \ldots . . .33$

Figure 21. Magnetic field distortion at the center of the top of the cylinder as the ratio of its height to the separation distance of the parallel plate waveguide at $2 \mathrm{MHz} . \ldots .34$

Figure 22. Magnetic field distortion at the center of the top of the cylinder as the ratio of its height to the separation distance of the parallel plate waveguide at $5 \mathrm{MHz} . \ldots .35$

Figure 23. Magnetic field distortion at the center of the top of the cylinder as the ratio of its height to the separation distance of the parallel plate waveguide at $10 \mathrm{MHz} \ldots . .36$

Figure 24. Magnetic field distortion at the center of the top of the cylinder as the ratio of its height to the separation distance of the parallel plate waveguide at $50 \mathrm{MHz} \ldots . .37$

Figure 25. Magnetic field distortion at the center of the top of the cylinder as the ratio of its height to the separation distance of the parallel plate waveguide at $100 \mathrm{MHz} . . .38$

Figure 26. Electric field distortion at the center of the top of the cylinder as the ratio of its height to the separation distance of the parallel plate waveguide............39 
Figure 27. Simuitaneous electric and magnetic field measurements using a doubly-loaded electrically small loop........40

Figure 28. Phase degradation of the TEM mode as the ratio of the cylinder height to the separation distance between the center conductor and the ground plane in the TEM cel1.......................... 
Theoretical and Experimental Investigations of Electromagnetic Field Distortion Due to a Perfectly Conducting Rectangular

Cylinder in a Transverse Electromagnetic Cell

\author{
Motohisa Kanda
}

Electromagnetic Fields Division
National Bureau of Standards
Boulder, Colorado 80303

The study of electromagnetic compatibility (EMC), that is the electronic and biological effects due to electromagnetic (EM) radiation, and EM calibration require accurate EM measurement techniques for defining the EM interference (EM) characteristics. Thus, fully enclosed rectangular transverse electromagnetic (TEM) transmission lines with thin inner conductors are often used for generating standard known test fields. In all cases it is desirable that only the dominant TEM mode should propagate.

In the EMC measurements, an object under test is placed inside of a TEM cell. The field from the TEM mode incident upon this scattering object is identical to that of a plane wave in a free space. However, the scattered field produced by the object in the TEM cell is different from the scattered field produced by the object in a free space, because of multiple reflections from the TEM cell walls, or equivalently, the mutual coupling between the object and the TEM cell.

The purpose of this paper is to discuss the loading effects, i.e., the electromagnetic field distortion caused by an object under test in a TEM cell. In the theoretical analysis, the frequency domain integral equation for the magnetic field, or equivalently, the current density on the surface of a perfectly conducting cylinder in a parallel plate waveguide is solved by the method of moments to predict the degree of magnetic field distortion.

The experimental investigations are performed by mounting a number of electrically small half loops on the surface of the perfectly conducting cylinder in a TEM cell. The loading effects in terms of magnetic field distortion are analyzed as the ratio of one of the object dimensions (height) to the separation distance between the inner conductor and the ground plane of the TEM cell. Also, the response of an electrically small loop to both the magnetic and electric components of the electromagnetic 
field is used to measure the phase relation between the magnetic and electric fields, which in turn can be used to determine the degree of degradation of the TEM mode due to the presence of the perfectly conducting cylinder. These theoretical and experimental results are compared with the available quasi electrostatic results.

Keywords: Eìectromagnetic Compatibility (EMC); Green's function; integral equation; linear equation; method of moments; parallel plate waveguide; quasi electrostatic; TEM cell.

\section{INTRODUCTION}

The study of electromagnetic compatibility (EMC), that is the electric and biological effects due to electromagnetic (EM) radiation, and EM calibration require accurate EM measurement techniques for defining the EM interference (EMI) characteristics. Thus, fully enclosed rectangular transverse electromagnetic (TEM) transmission lines with thin inner conductors are often used for generating standard known test fields. In all cases, it is desirable that only the dominant TEM mode should propagate. Thus, the usefulness of these structures is limited to a frequency region below some upper frequency bound in order to suppress the higher order modes.

The higher order mode cutoff frequencies of the rectangular TEM cell have been well studied by many workers $[1,2,3,4]$. While in a rectangular hollow waveguide, the dominant mode is always the $\mathrm{TE}_{10}$ mode as long as the width exceeds the height, the same conclusion does not hold for the rectangular line with an inner conductor even if its thickness is infinitesimally small. In fact, it is found $[1,2,4]$ that, depending on the width of the inner conductor and the size of the TEM cel1, the cutoff frequency of the $\mathrm{TE}_{01}$ mode can be much lower than that 
of the $T E_{10}$ mode as $i l l u s t r a t e d$ in figure 1. While the cutoff frequency of the $T E_{10}$ mode is simply calculated from

$$
f_{c}=\left.\frac{1}{2 \sqrt{\mu \varepsilon}} \sqrt{\left(\frac{m}{a}\right)^{2}+\left(\frac{n}{b}\right)^{2}}\right|_{\begin{array}{c}
m=1 \\
n=0
\end{array}}=\frac{1}{2 a \sqrt{\mu \varepsilon}},
$$

the cutoff frequencies of the $\mathrm{TE}_{01}$ mode are much more involved and have been calculated by many workers $[1,2,3,4]$ as shown in figure 2 . Let us consider, for example, a typical 50 TEM cell having a width of a $=1 \mathrm{~m}$, a height of $b=0.6 \mathrm{~m}$, and a width of inner conductor of $\mathrm{s}=0.72 \mathrm{~m}$. While the cutoff frequency of the $\mathrm{TE}_{10}$ mode is $150 \mathrm{MHz}$, the cutoff frequency of the $\mathrm{TE}_{01}$ mode is approximately $135 \mathrm{MHz}$ according to figure 2. It can also be shown that the cutoff frequencies of all TM modes of a TEM cell are always higher than those of their hollow waveguide counterparts. Thus, the dominant cutoff frequency (i.e., the lowest) is either the $\mathrm{TE}_{01}$ mode or the $\mathrm{TE}_{10}$ mode. It is interesting to note that the cutoff frequency of the $\mathrm{TE}_{01}$ mode decreases as the gap between the inner conductor and the wall of the TEM cell becomes narrower. This phenomenon has also been observed in a ridge waveguide [5] and is associated with the infinite gap capacitance.

In the EMC measurements, an object under test is placed inside of a TEM cell. The field from the TEM mode incident upon the scattering object is identical to that of a plane wave in a free space. However, the scattered field produced by the object in the TEM cell is different from the scattered field produced by the object in a free space because of multiple reflections from the TEM cell walls, or equivalently, the mutual coupling between the object and the TEM cell. 
Placing a test object in a TEM cell is equivalent to introducing a capacitive discontinuity. For low frequencies, where the transverse dimensions of the object are negligible compared to the wavelength, the discontinuity due to the object is a pure capacitive reactance, and may be regarded as the fringing capacitance of the corresponding electrostatic problems. Under this assumption, the ratio of the electric field strength near the metal object in the TEM cell to the unperturbed electric field strength at the same location in a pure TEM mode has been calculated by G. Meyer [6] and is shown in figure 3.

The purpose of this paper is to discuss the loading effects, i.e., the electromagnetic field distortion caused by an object under test in a TEM ce11. In the theoretical analysis, the frequency domain integral equation for the magnetic field, or equivalently, the current density on the surface of a perfectly conducting cylinder in a parallel plate waveguide is solved by the method of moments to predict the degree of mangetic field distortion. For the purpose of mathematical tractability, a parallel plate waveguide is used to model a TEM cell structure. The results given in the paper are for the magnetic field intensity on the surface of the cylinder. Other related quantities, such as the electric field intensity and the poynting vector, can be readily derived from the surface current by use of Maxwell's equations.

\section{THEORY}

The problem of determining the electromagnetic field scattered by a perfectly conducting rectangular cylinder has been studied by many 
workers $[7,8,9]$. The coordinate system used to analyze the current density on the surface of the rectangular cylinder in a parallel plate waveguide is shown in figure 4 . The source of the TEM wave is a delta function voltage source of the form

$$
\vec{M}=\vec{y} v_{0}(\omega) \delta\left(z-z_{0}\right) \text {, }
$$

where $V_{0}$ is the magnitude of an equivalent voltage source located at the source location $z_{0}$. Since there is no variation in the $y$ direction and the voltage source has only a $y$-component, we will have a scalar wave equation in $H_{y}$, i.e.,

$$
\nabla^{2} H_{y}+k^{2} H_{y}=j \omega \varepsilon M_{y} \text {, }
$$

where $\nabla^{2}=\frac{\partial^{2}}{\partial x^{2}}+\frac{\partial^{2}}{\partial z^{2}}$ and $k$ is the free space wave number. The boundary condition is that the normal $\vec{H}$ field be zero on all of the reflecting conducting surfaces, i.e.

$$
\frac{\partial H_{y}}{\partial n}=0
$$

where $n=x$ and $z$.

The solution of equation (3) may be found through the Green's Function technique,

$$
\nabla^{2} G\left(r, r^{\prime}\right)+k^{2} G\left(r, r^{\prime}\right)=-\delta\left(x-x^{\prime}\right) \delta\left(z-z^{\prime}\right) \text {. }
$$


Multiplying eq. (3) by $G\left(r, r^{\prime}\right)$, eq. (5) by $H_{y}$, subtracting the two results and integrating over the free space volume $V$,

$$
\begin{gathered}
\int_{v}\left[G\left(r, r^{\prime}\right) \nabla^{2} H_{y}\left(r^{\prime}\right)-H_{y}\left(r^{\prime}\right) \nabla^{2} G\left(r, r^{\prime}\right)\right] d v^{\prime} \\
=j \omega \varepsilon \int_{v} G\left(r, r^{\prime}\right) M_{y}\left(r^{\prime}\right) d v^{\prime}+\int_{v} H_{y}\left(r^{\prime}\right) \delta\left(x-x^{\prime}\right) \delta\left(z-z^{\prime}\right) d v^{\prime} .
\end{gathered}
$$

Evaluating the integration of the right hand side of eq. (6) and using Green's theorem on the left hand side, we get

$$
\begin{aligned}
\int_{S} & {\left[G\left(r, r^{\prime}\right) \frac{\partial H\left(r^{\prime}\right)}{\partial n^{\prime}}-H_{y}\left(r^{\prime}\right) \frac{\partial G\left(r, r^{\prime}\right)}{\partial n^{\prime}}\right] d s^{\prime} } \\
& =j \omega \varepsilon \int_{V} G\left(r, r^{\prime}\right) M_{y}\left(r^{\prime}\right) d v^{\prime}+H_{y}(r) .
\end{aligned}
$$

On the perfectly conducting surface, $s$, of the plates, we set the boundary condition as

$$
\frac{\partial H_{y}\left(r^{\prime}\right)}{\partial n^{\top}}=0
$$

Equation 7 then reduces to

$$
\left.H_{y}(r)=-j \omega \varepsilon \int_{v^{\prime}} G\left(r, r^{\prime}\right) M_{y} r^{\prime}\right) d v^{\prime}-\int_{S_{C}} H_{y}\left(r^{\prime}\right) \frac{\partial G\left(r, r^{\prime}\right)}{\partial n^{\prime}} d s^{\prime} \text {, }
$$

where $\mathrm{s}_{\mathrm{C}}$ indicates the surface of the rectangular cylinder. The first term on the right hand side of eq. (9) corresponds to the incident field, and the second term to the scattered field. The known incident 
magnetic field is given by

$$
\begin{aligned}
H^{i n c}(x, z) & =-j \omega \varepsilon \int_{0}^{\infty} \int_{0}^{b} v_{0} \delta\left(z^{\prime}-z_{0}\right) G\left(x, z ; x^{\prime}, z^{\prime}\right) d x^{\prime} d z^{\prime} \\
& =\frac{\omega \varepsilon}{k} v_{0} e^{j k z} \cos k z .
\end{aligned}
$$

Equation (9) is an integral equation which can be solved for $H_{y}(r)$ once Green's function $G\left(r, r^{\prime}\right)$ is obtained.

The Green's function is the solution of eq. (5). By imposing the proper boundary condition for the parallel plate waveguide, i.e.

$$
\frac{\partial G}{\partial x}=0
$$

at $x=0$ and $x=b$, then one finds [10]

$$
\begin{gathered}
G\left(x, z ; x^{\prime}, z^{\prime}\right)=\frac{j}{2 k b}\left[e^{j k\left(z+z^{\prime}\right)}+e^{j k\left|z-z^{\prime}\right|}\right] \\
+\frac{j}{b} \sum_{n=1}^{\infty} \frac{\cos \frac{n \pi x}{b} \cos \frac{n \pi x^{\prime}}{b}}{\Gamma_{n}}\left[e^{j \Gamma n\left(z+z^{\prime}\right)}+e^{j \Gamma n\left|z-z^{\prime}\right|}\right],
\end{gathered}
$$

where

$$
\Gamma_{n}=\sqrt{k^{2}-\left(\frac{n \pi}{b}\right)^{2}}
$$

Once the Green's function is obtained and the source is specified, eq. (9) can be solved by the method of moments. The technique used is discussed briefly below. A detailed discussion on this subject is given 
by Harrington [11].

The unknown $\mathrm{H}_{y}$ is expanded in terms of a set of known basis functions $f_{i}$ with unknown coefficients $\alpha_{i}$, i.e.

$$
H_{y}=\sum_{i=1}^{n} \alpha_{i} f_{i}
$$

Substituting eq. (14) into eq. (9) we obtain

$\sum_{i=1}^{n} \alpha_{i}\left[f_{i}(x, z)+\int_{s^{\prime}} f_{i}\left(x^{\prime}, z^{\prime}\right) \frac{\partial G\left(x, z ; x^{\prime}, z^{\prime}\right)}{\partial n^{\prime}} d s^{\prime}\right]=H^{i n c}(x, z)$.

Equation (15) is a single equation with $n$ unknown $\alpha_{i}$. To create at least $n$ linear equations, a set of testing function, $w_{j}$, is introduced, and the inner products (integral over the surface) of both sides of eq. (15) for each $w_{j}$ are set equal. This forms a set of linear equations of the form

$$
[Z][I]=[\mathrm{V}] \text {, }
$$

where the matrix element $z_{i j}$ is given by

$$
z_{i j}=\int_{s}\left[f_{i}(r)+\int_{s^{\prime}} f_{i}\left(r^{\prime}\right) \frac{G\left(r, r^{\prime}\right)}{\partial n^{\prime}} d s^{\prime}\right] w_{j}(r) d s,
$$

and the column matrix element $v_{j}$ is given by

$$
v_{j}=\int_{s} H^{i n c}(r) w_{j}(r) \text { ds. }
$$

The unknown coefficients $\alpha_{j}$ are found by solving the matrix eq (16). 
The expression for $H_{y}$ is then given by eq (14).

\section{THEORETICAL AND EXPERIMENTAL RESULTS}

A number of electrically small half loops whose diameters are $1.5 \mathrm{~cm}$ are mounted transversely across a perfectly conducting rectangular cylinder. The cylinder is placed in a TEM cell which acts approximately as a parallel plate waveguide. A vector voltmeter is used to measure both the magnitude and phase of the magnetic field strength and therefore the current density on the surface of the cylinder. In the theoretical analysis, the frequency domain integral equation for the magnetic field on the surface of the cylinder in a parallel plate waveguide given in section II is solved by the method of moments. Other related quantities, such as the electric field intensity and the poynting vector can be readily derived from the surface current by use of Maxwell's equations.

In this paper, the loading effects due to the perfectly conducting rectangular cylinder in a TEM cell are indicated in terms of the magnetic field distortion, which is defined as the ratio of the magnetic field strength on the surface of the cylinder in a TEM cell to that at the same position in an empty TEM cell. In this paper, the separation distance of the parallel plate waveguide, i.e., the distance between the center conductor and the ground $\mathrm{plane}$ in the TEM cell is chosen to be $30 \mathrm{~cm}$. Three different perfectly conducting rectangular cylinders are used, all of which have the same widths of $18 \mathrm{~cm}$, but have different heights of $5.5 \mathrm{~cm}, 15 \mathrm{~cm}$, and $18 \mathrm{~cm}$. The magnetic field distortion and 
the corresponding phase are shown in figures 5 through 20 for frequencies from $1 \mathrm{MHz}$ to $100 \mathrm{MHz}$. The phase reference is taken to be at the center of the top of the cylinder $\left(x=h\right.$ and $\left.\frac{\ell}{2}\right)$. Figures 21 through 25 show the magnetic field distortion at the center of the top of the cylinder as the ratio of its height to the separation distance of the TEM cell. For a comparison, the electric field distortion due to a metal cube reported by $G$. Meyer [6] is al so shown in these figures. In general, it is found that the magnetic field distortion due to a perfectly conducting rectangular cylinder is quite small and much less than the electric field distortion reported by G. Meyers [6].

In order to confirm the result by G. Meyer [6], a electrically small dipole is mounted on the center of the top of the perfectly conducting rectangular cylinder. The electric field distortion (defined as the ratio of electric field at the surface of the cylinder to that at the same position in an empty TEM cell) is shown in figure 26 as the ratio of the cylindrical height to the separation distance of the parallel plate waveguide. Figure 26 indicates that the electric field distortion is much larger than that predicted by G. Meyer [6]. The discrepancy may be due to the fact that the Meyer calculation is based on the quasi electrostatic approximation.

When the perfectly conducting rectangular cylinder is placed in the TEM cell, the scattered field produced by the cylinder can be far different from the original incident TEM mode. In order to determine the degree of degradation of the TEM mode due to the presence of the cylinder, the response of an electrically small loop to both the magnetic and electric components of an electromagnetic field is 
examined. Consider the loop loaded at each of the diametrically opposite points as shown in figure 27. One can show that the sum of the two load currents $I_{\Sigma}$ is given by [12]

$$
I_{\Sigma}=K_{h} H_{y},
$$

and their difference $I_{\Delta}$ is given as

$$
I_{\Delta}=K_{e} E_{x},
$$

where $k_{h}$ and $k_{e}$ are, respectively, the loop sensitivity constant for magnetic and electric fields. These formulas clearly show that the use of the sum current gives a measure of the magnetic field, whereas that of its difference gives a measure of the electric field.

While the phase between magnetic and electric field is normally in phase for the pure TEM mode, the presence of the perfectly conducting rectangular cylinder in the TEM cell will cause a distortion and thus a phase degradation of the TEM mode around the cylinder. The phase degradation of the TEM mode thus obtained is shown in figure 28 as the ratio of the cylinder height to the separation distance of the TEM cell. It is very interesting to note that the phase degradation at the center of the cylinder becomes predominant as the frequency approaches to the cutoff frquency of the $\mathrm{TE}_{01}$ mode and also the height of the cylinder becomes comparably large compared to the separation of the parallel plate waveguide. The phase degradation observed at the low frequencies around $2 \mathrm{MHz}$ is not well understood, but is probably due to the experi- 
mental problems caused by the vector voltmeter and the hybrid junction used in the experiments.

\section{CONCLUSIONS}

This paper discussed the loading effects, i.e., the electromagnetic field distortion caused by a metal object placed in a TEM cell. In the theoretical analysis, the frequency domain integral equation for the magnetic field intensity on the surface of a perfectly conducting cylinder in a parallel plate waveguide was solved by the method of moments to obtain the degree of magnetic field distortion. The results given in the paper are for the magnetic field intensity on the surface of the cylinder. Other related quantities, such as the electric field intensity and the poynting vector can be readily derived from the surface current by use of Maxwell's equations.

The experimental investigations were performed by mounting a number of electrically small half loops on the surface of a perfectly conducting cylinder placed in a TEM cel1. The loading effects in terms of magnetic field distortion were expressed as the ratio of the object height to the separation distance between the inner conductor and the ground plane of the TEM cell. Also, the response of an electrically smal1 loop to both the magnetic and electric components of an electromagnetic field was used to measure the phase relation between the magnetic and electric fields, which in turn was used to assess the degree of degradation of the TEM mode due to the presence of the perfectly conducting cylinder. These theoretical and experimental 
results were compared with the available quasi electrostatic results.

\section{REFERENCES}

[1] Brackelmann, W., Landmann, D., and Schlosser, W., Die Grenzfrequenzen von hoheren Eigenwellen in Streifenleitungen AEU, Vol. 21, pp 112-120 (March 1967).

[2] Gruner, L., High Order Modes in Rectangular Coaxial Waveguides, IEEE Trans. Microwave Theory Technique, Vol MTT-15, pp. 483-485, (August 1967).

[3] Mittra, R., and Itoh, T., A New Technique for the Analaysis of the Dispersion Characteristics of Microstrip Lines, IEEE Trans. Microwave Theory Technique, Vol MTT-19, pp. 47-56, (January 1971).

[4] Tippet, J. C., Modal Characteristics of Rectangular Coaxial Transmission Line, Ph.D Thesis, University of Colorado, Boulder, CO. (June 1978).

[5] Ramo, S., and Whinnery, J. R., Fields and Waves in Modern Radio, 2nd Edition, John Wiley \& Sons, Inc., New York, N. Y. (1953).

[6] Meyer, G., Application of a Broadband Measuring Line in Field Immunity Testing, 2nd Symposium and Technical Exhibition on Electromagnetic Compatibility, Montreux, Switzerland, pp. 241-46, (June 1977).

[7] Mei, K., and Van Bladel, J. G., Low-Frequency Scattering by Rectangular Cylinders, IEEE Trans. Antennas and Propagation, Vol. AP-11, pp. 52-56, (January 1963).

[8] Mei, K. K. and Van Bladel, J. G., Scattering by Perfectly Conducting Rectangular Cylinders, IEEE Trans. Antennas and Propagation, Vol. AP-11, pp. 185-192, (March 1963).

[9] Andreasen, M. G., Comments on Scattering by Conducting Rectangular Cylinders, IEEE Trans. Antennas and Propagation, Vol. AP-12, pp. 235-236, (March 1964).

[10] Morse, P. M. and Feshback, H., Methods of Theoretical Physics, McGraw-Hill Book Company, Inc., New York, (1953).

[11] Harrington, R. F., Field Computation by Moment Methods, the Macmillan Company, New York, (1968).

[12] Whiteside, H. and King, R.W.P., The Loop Antenna as a Probe, IEEE Trans. Antennas and Propagation, Vol. AP-19, No. 3, pp. 291-297, (May 1964). 


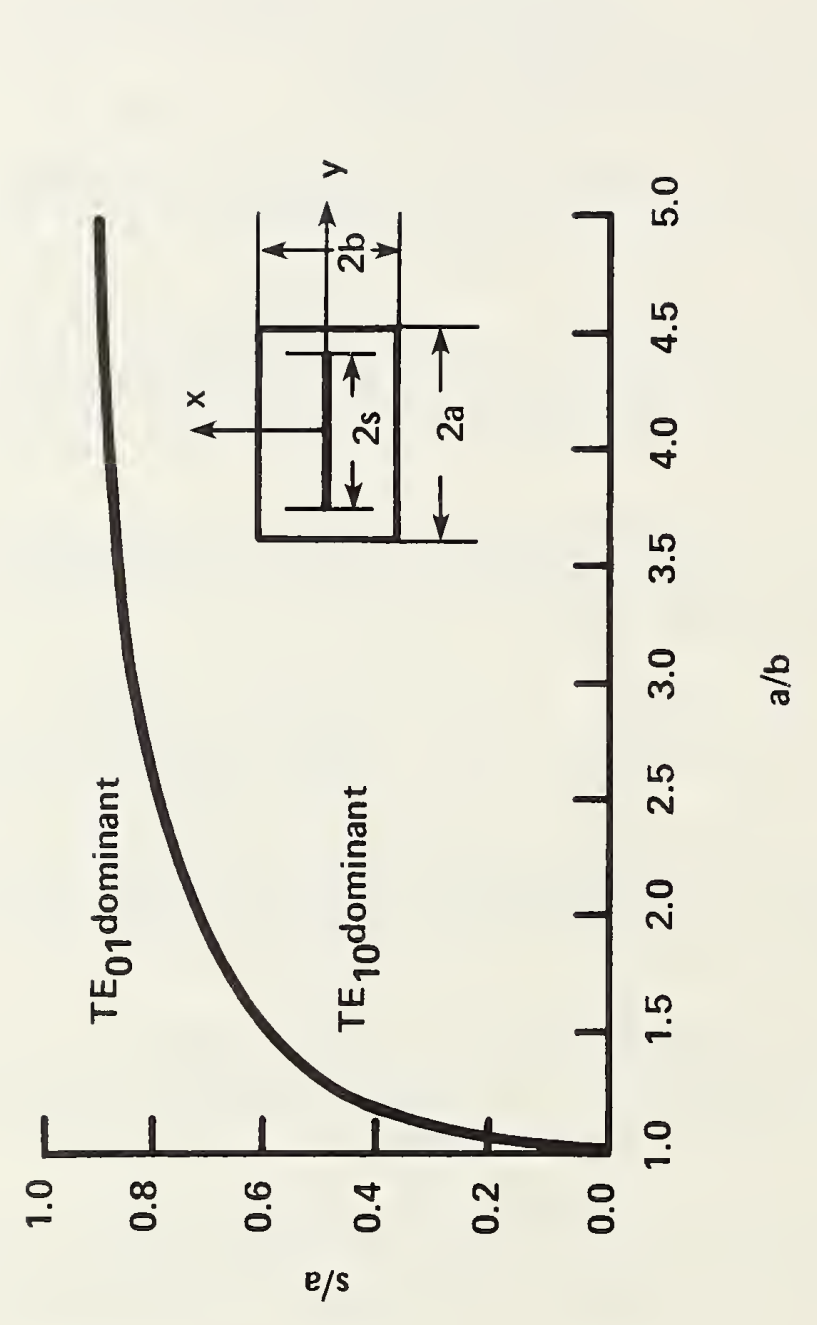

0
5
4

ปั)

4

$+$

동

언

㟔.

믐

도융

ธัช

웡

$\leftarrow \frac{n}{\circ}$

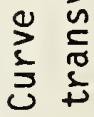

-1
0
$\frac{5}{5}$
는 


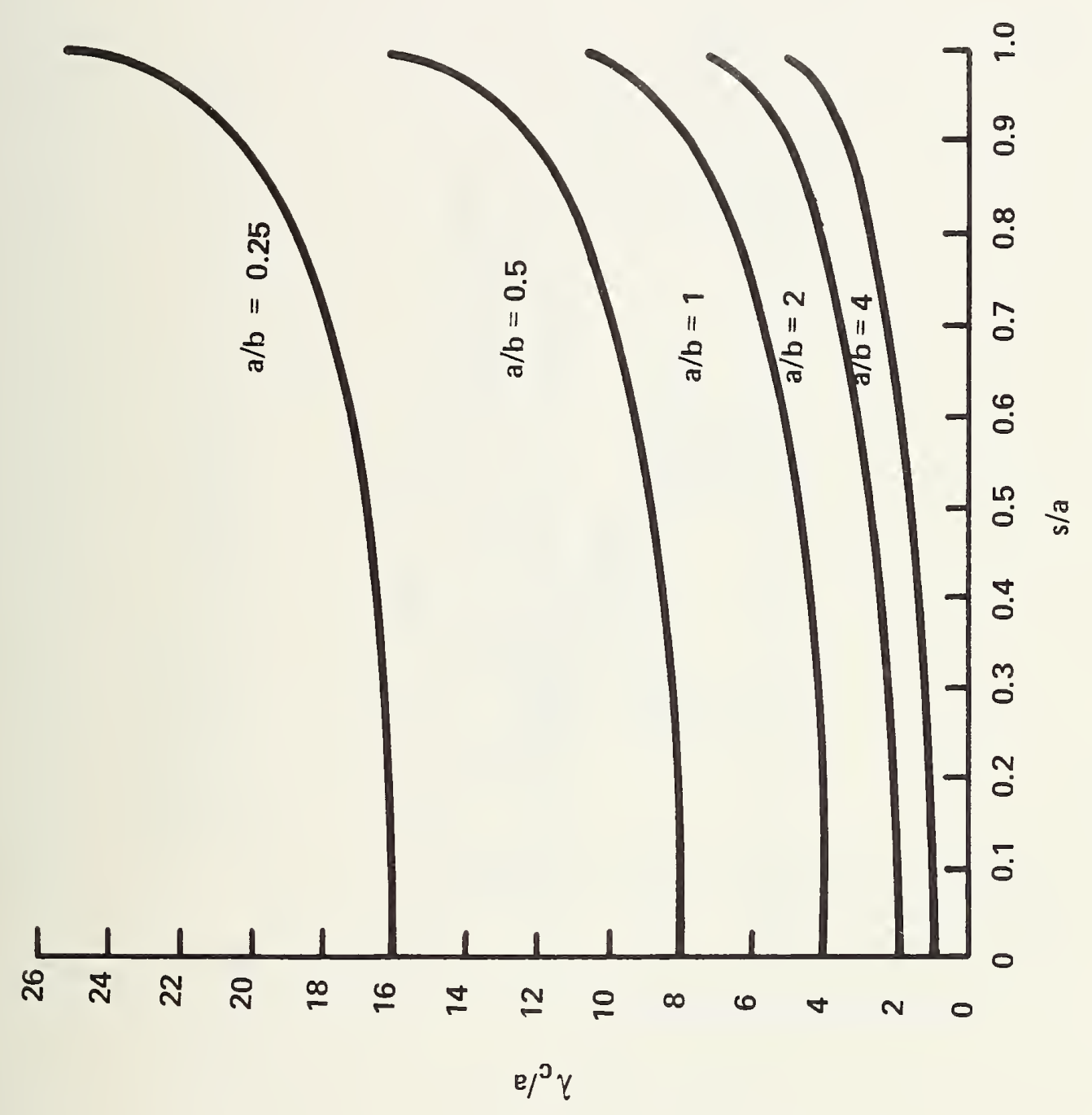

崩

10
4
4

$\frac{1}{10}$
$\frac{1}{0}$
$\frac{1}{3}$
$\frac{0}{3}$

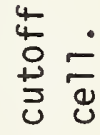

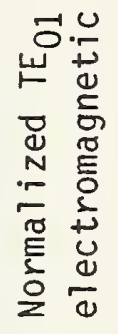

i

永 


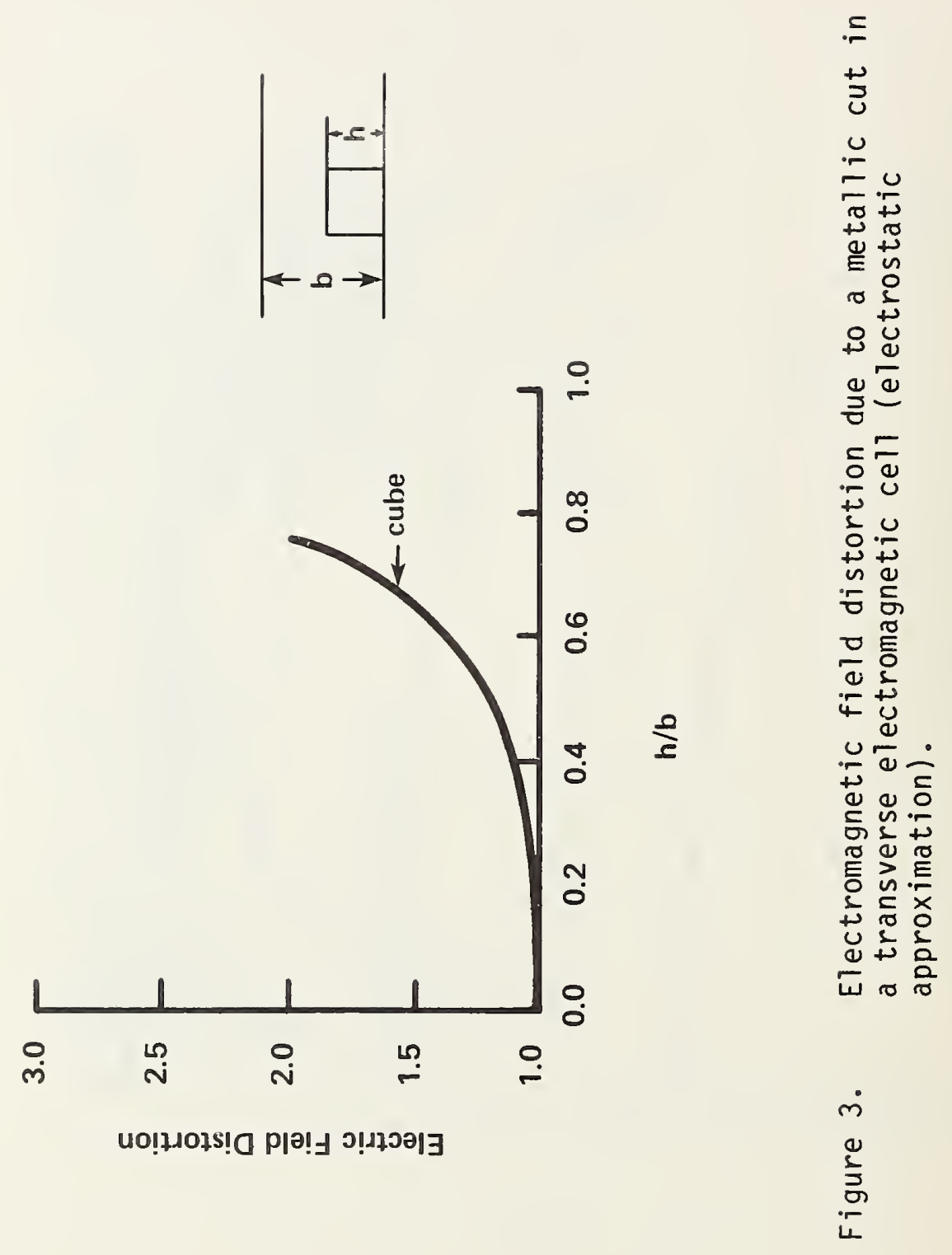




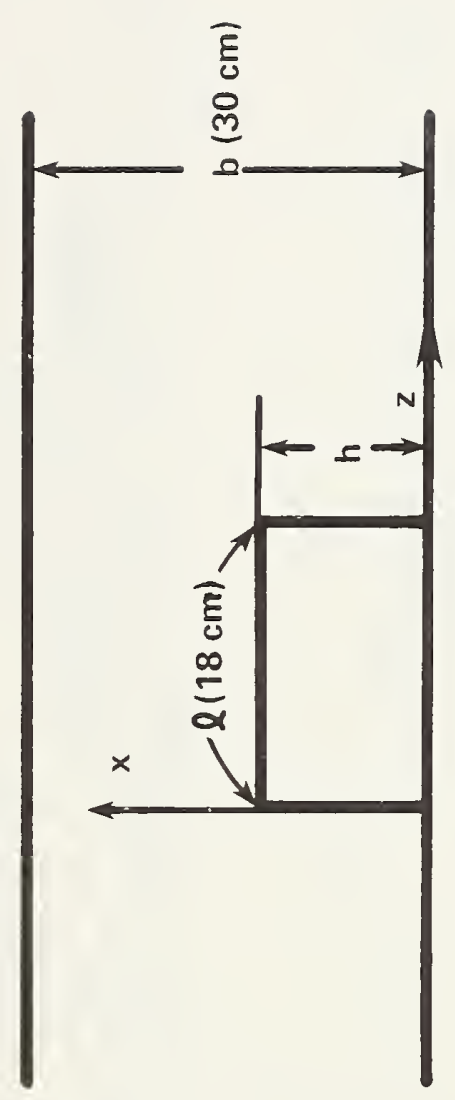

$\frac{\pi}{\frac{0}{6}}$

ro

ᄃ

文

宪

б

4

틈

$\stackrel{ \pm}{\sim}$

जे

$\stackrel{4}{\longrightarrow}$

일

(

용

$8 \frac{\pi}{0}$

$\dot{\sigma}$

竔 


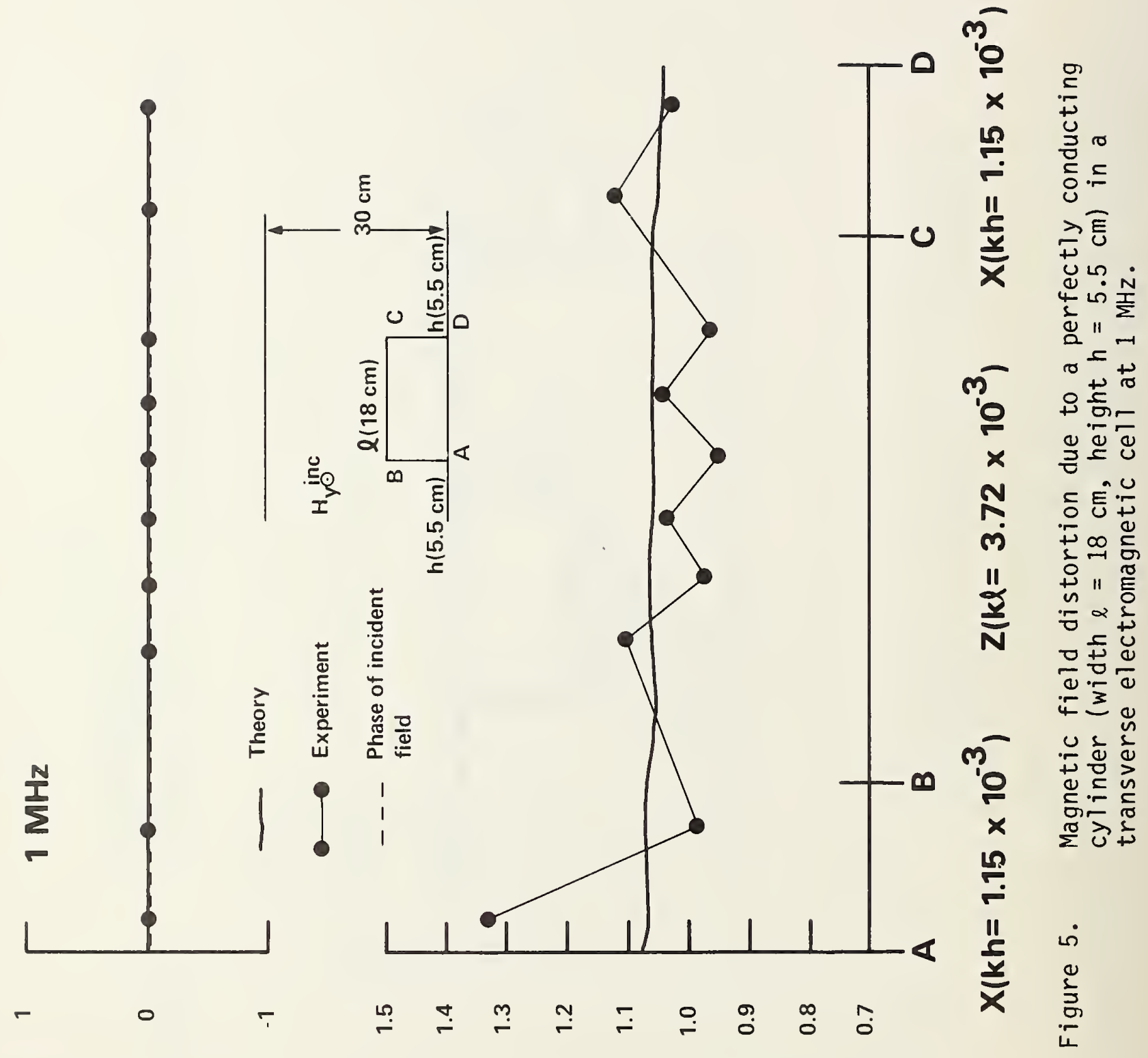

รәวเ6ә0 u! әseपd

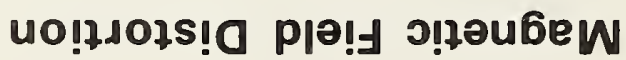




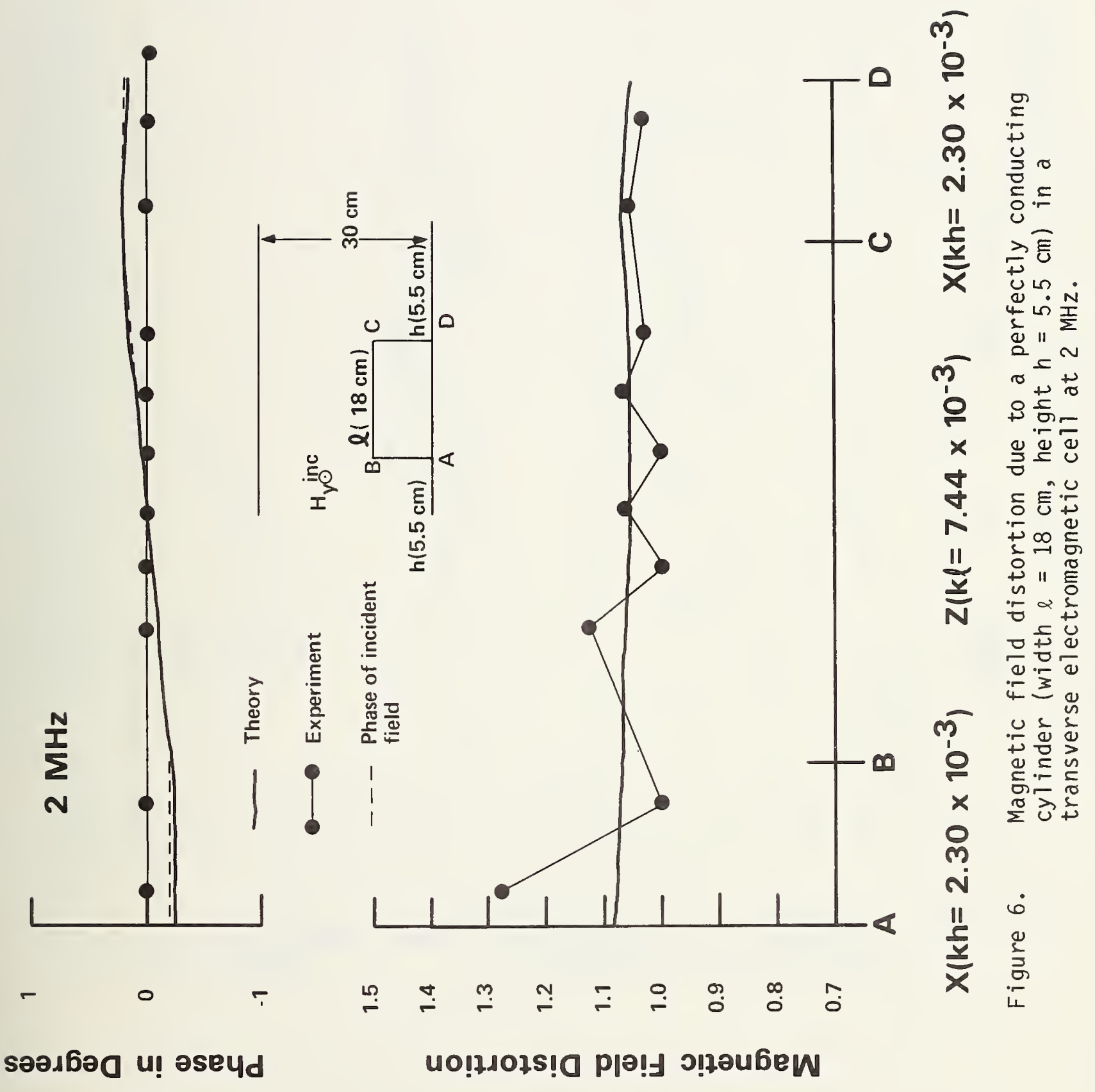




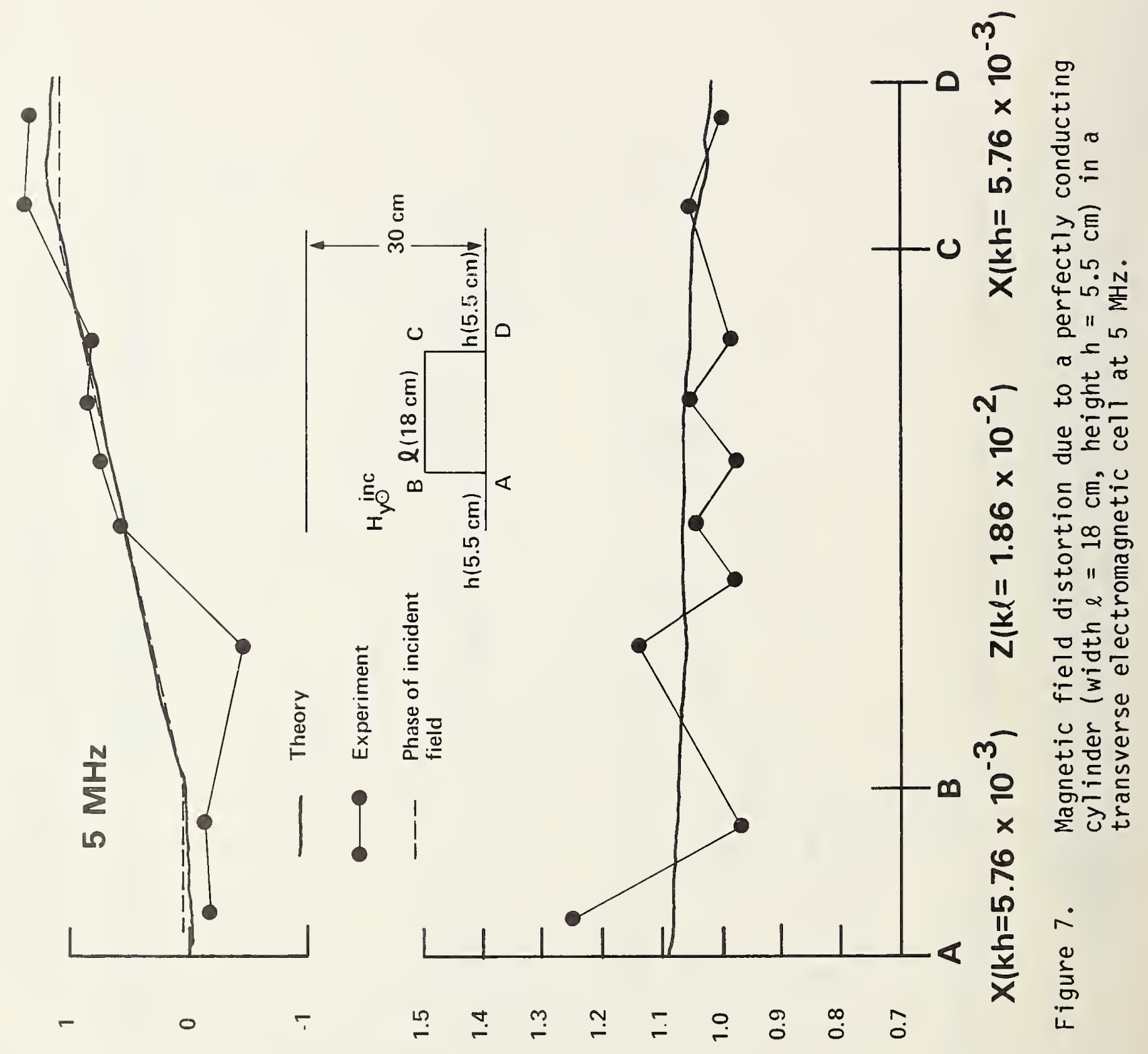

sәəљ6ә0 u! әseчd

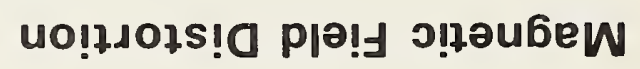




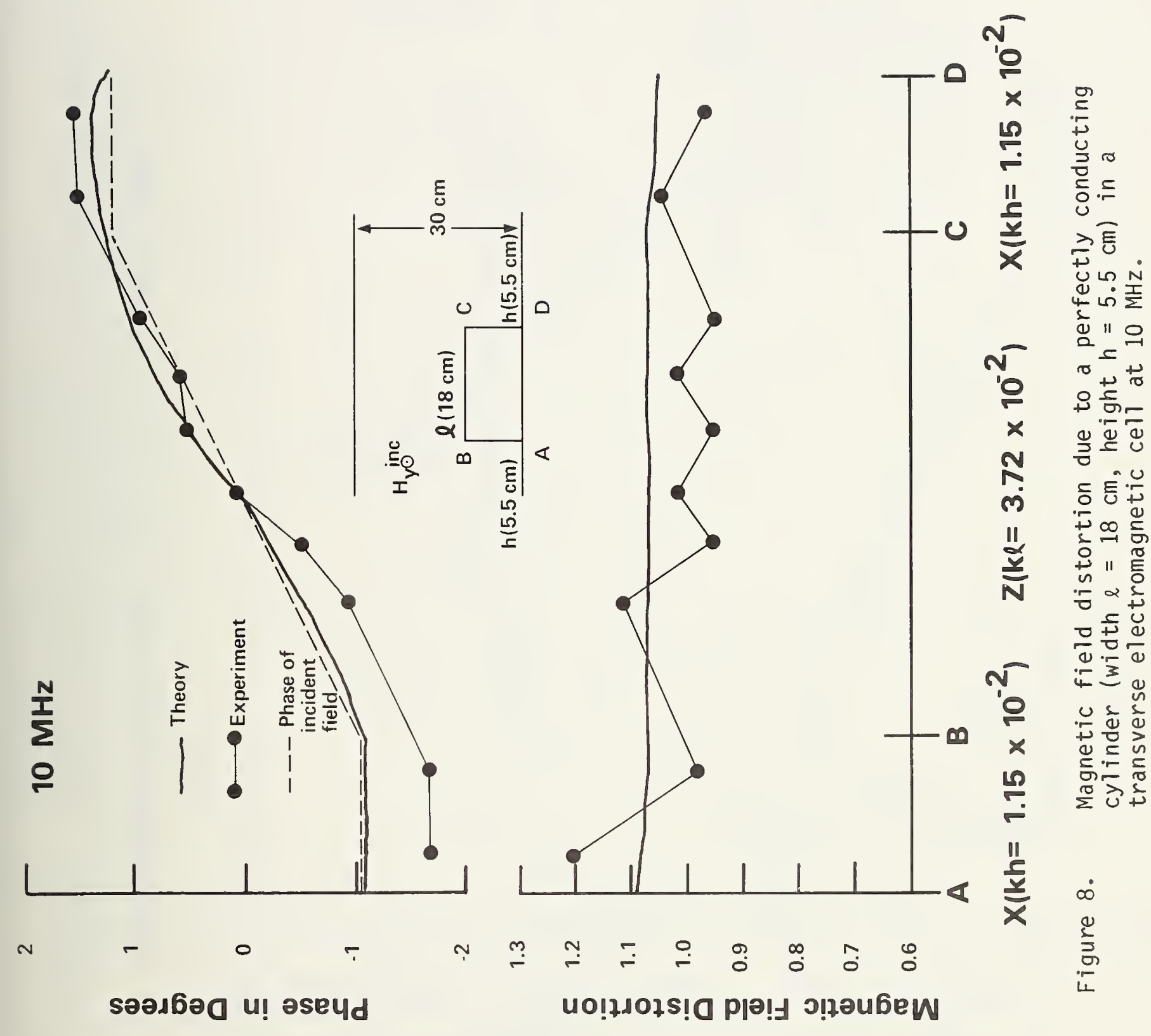



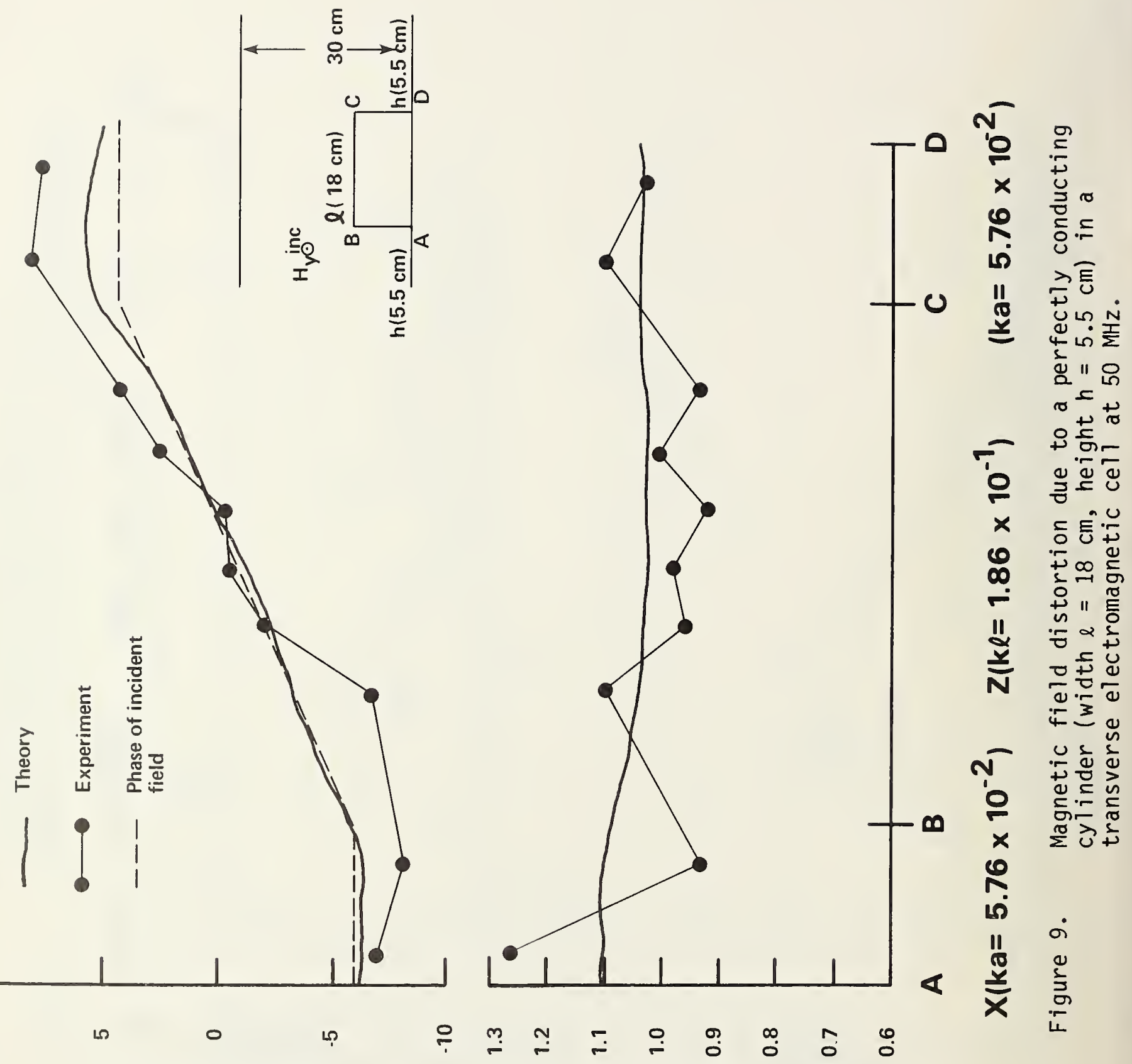

รәวง6ว0 u! วseบd

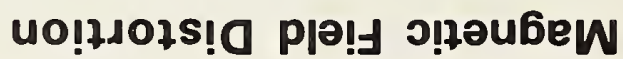




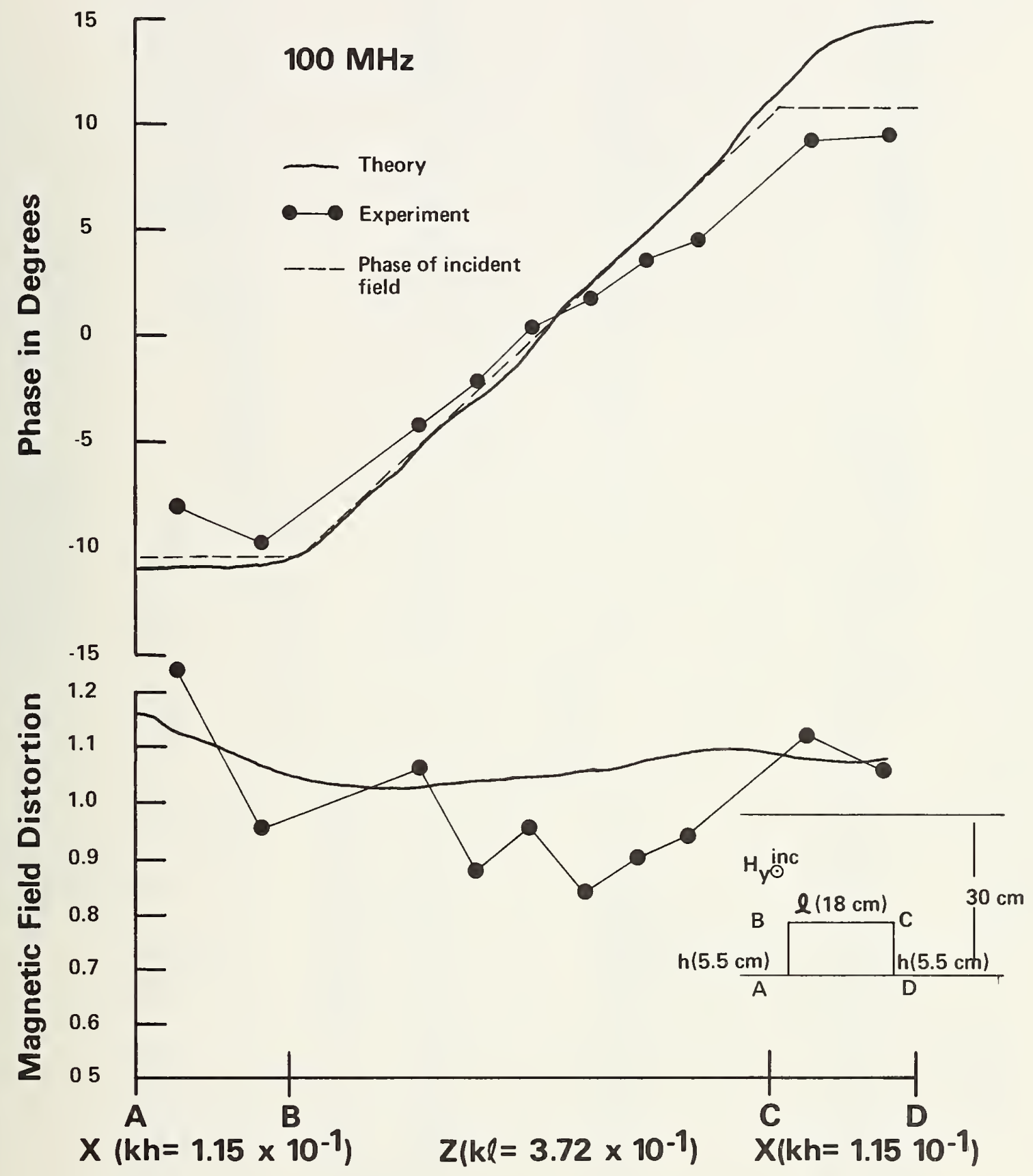

Figure 10. Magnetic field distortion due to a perfectly conducting cylinder (width $\ell=18 \mathrm{~cm}$, height $h=5.5 \mathrm{~cm}$ ) in a transverse electromagnetic cell at $100 \mathrm{MHz}$. 


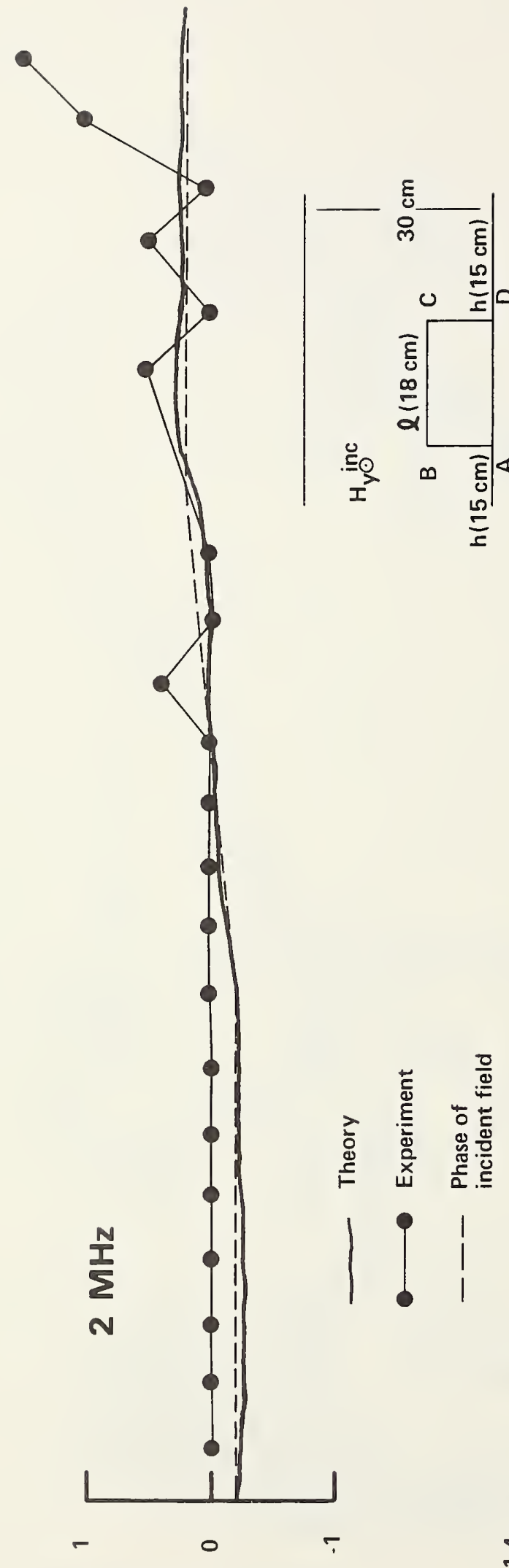

รәәд6әด u! әseчd

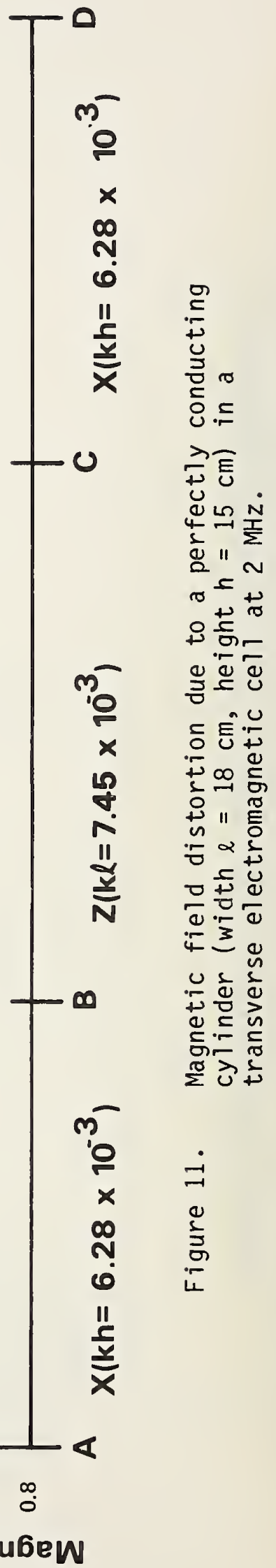

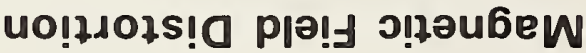




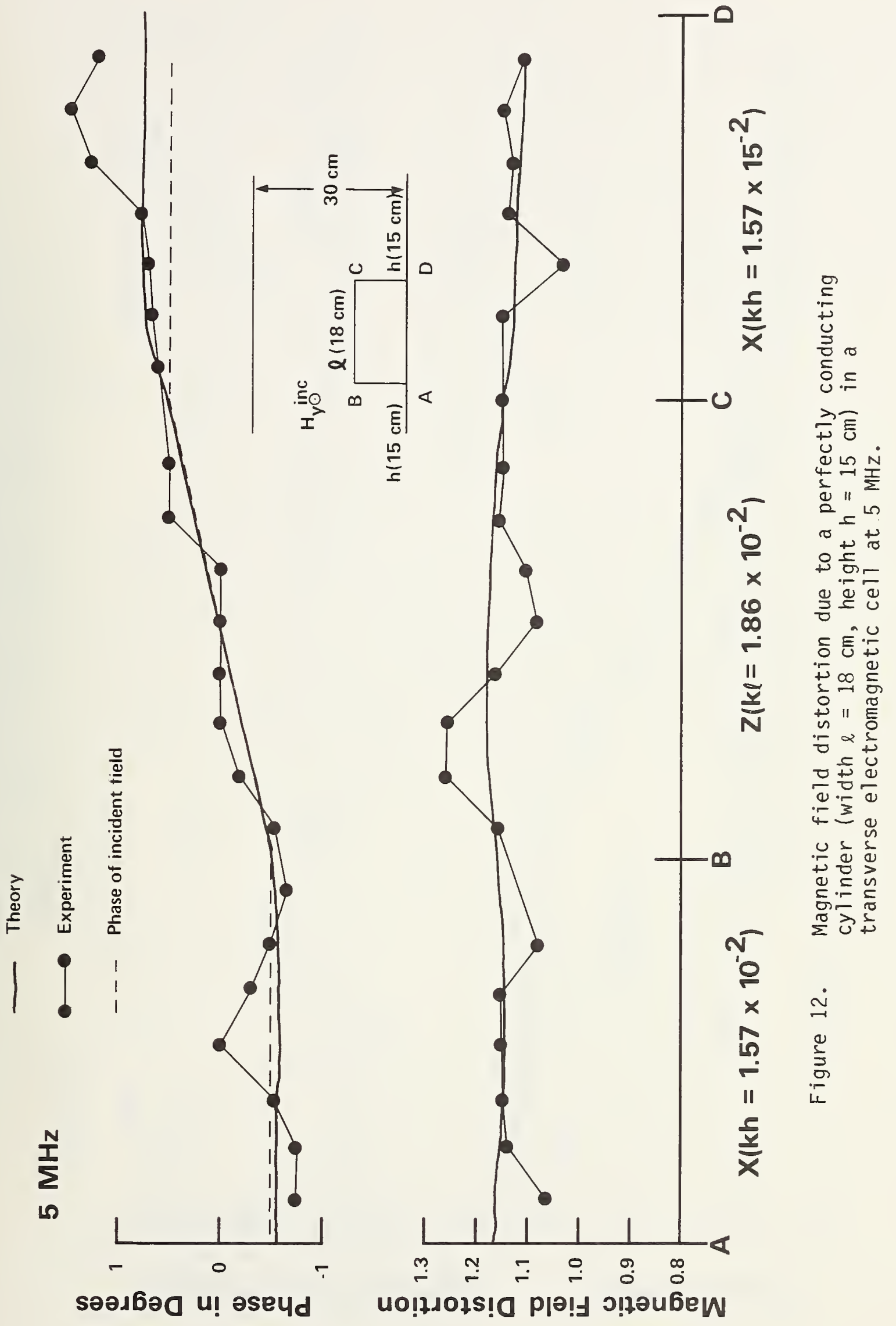




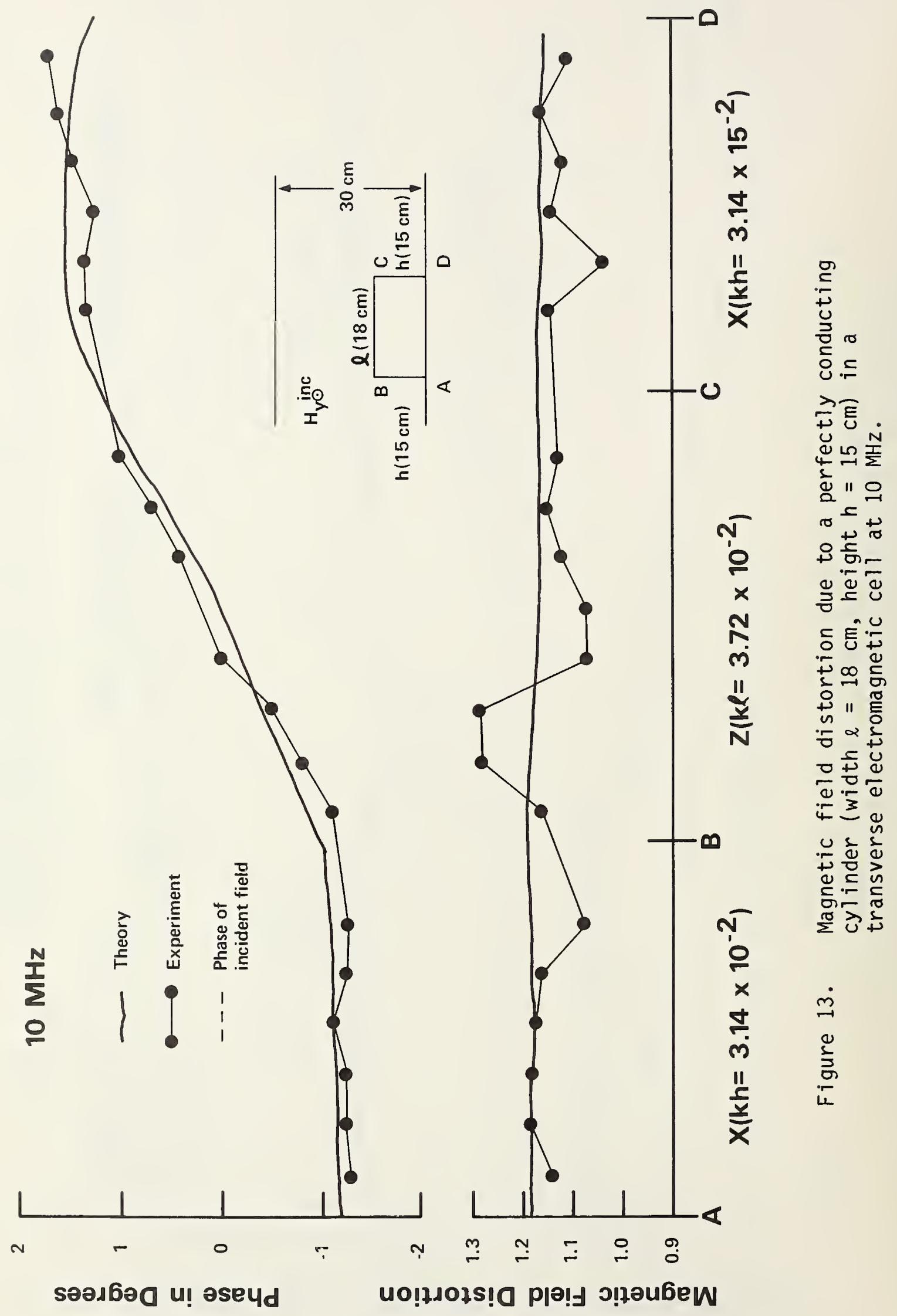




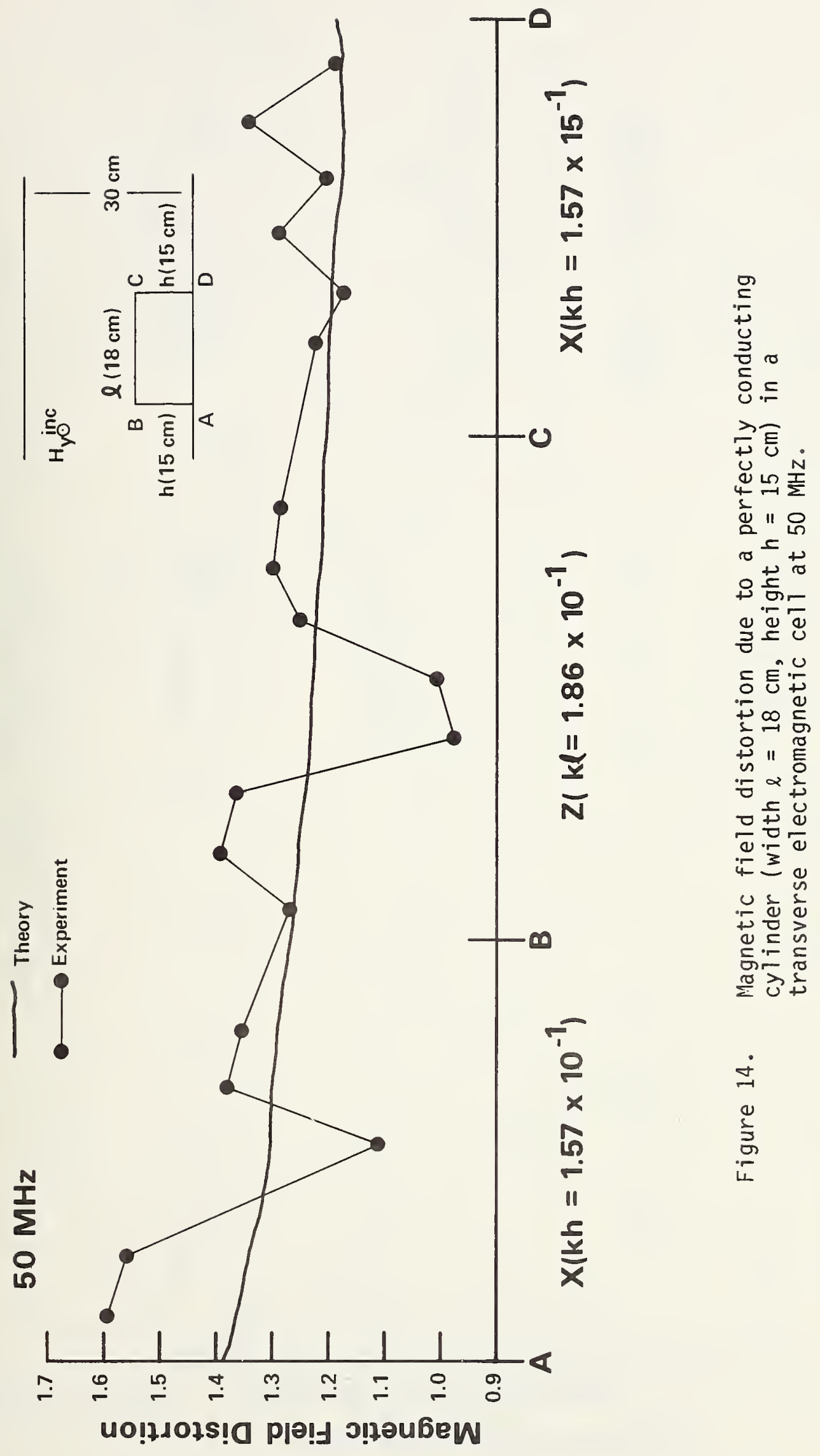




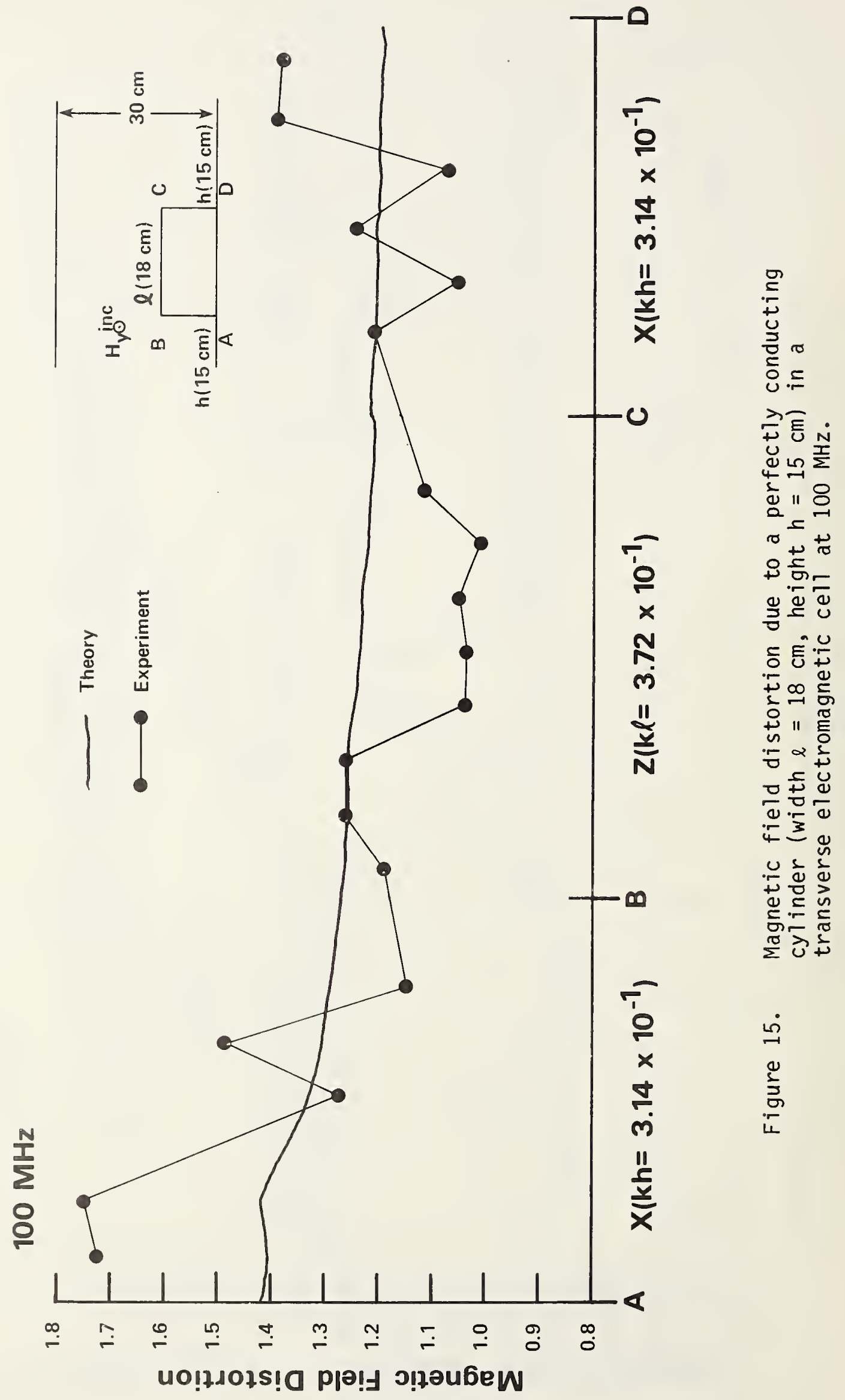




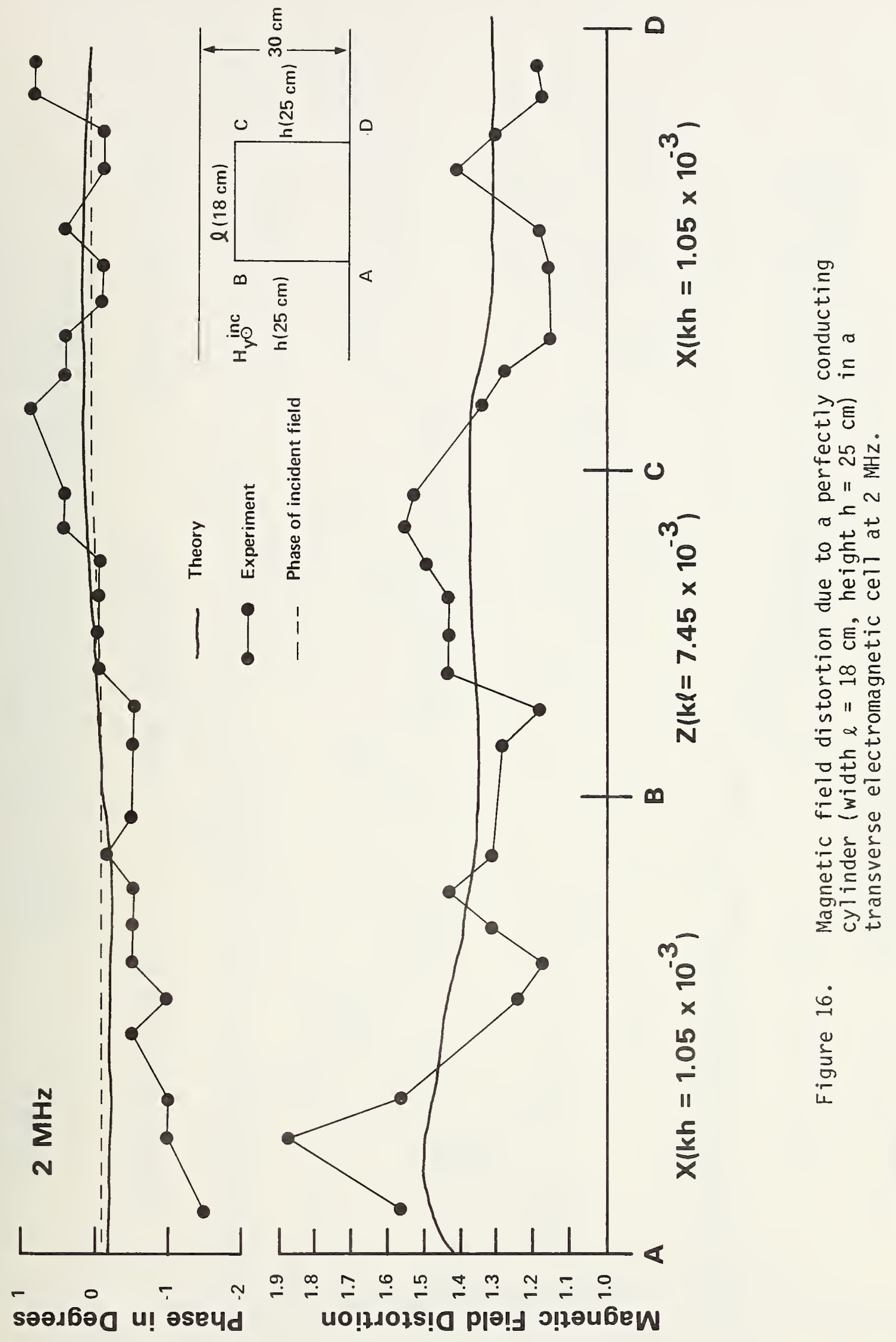




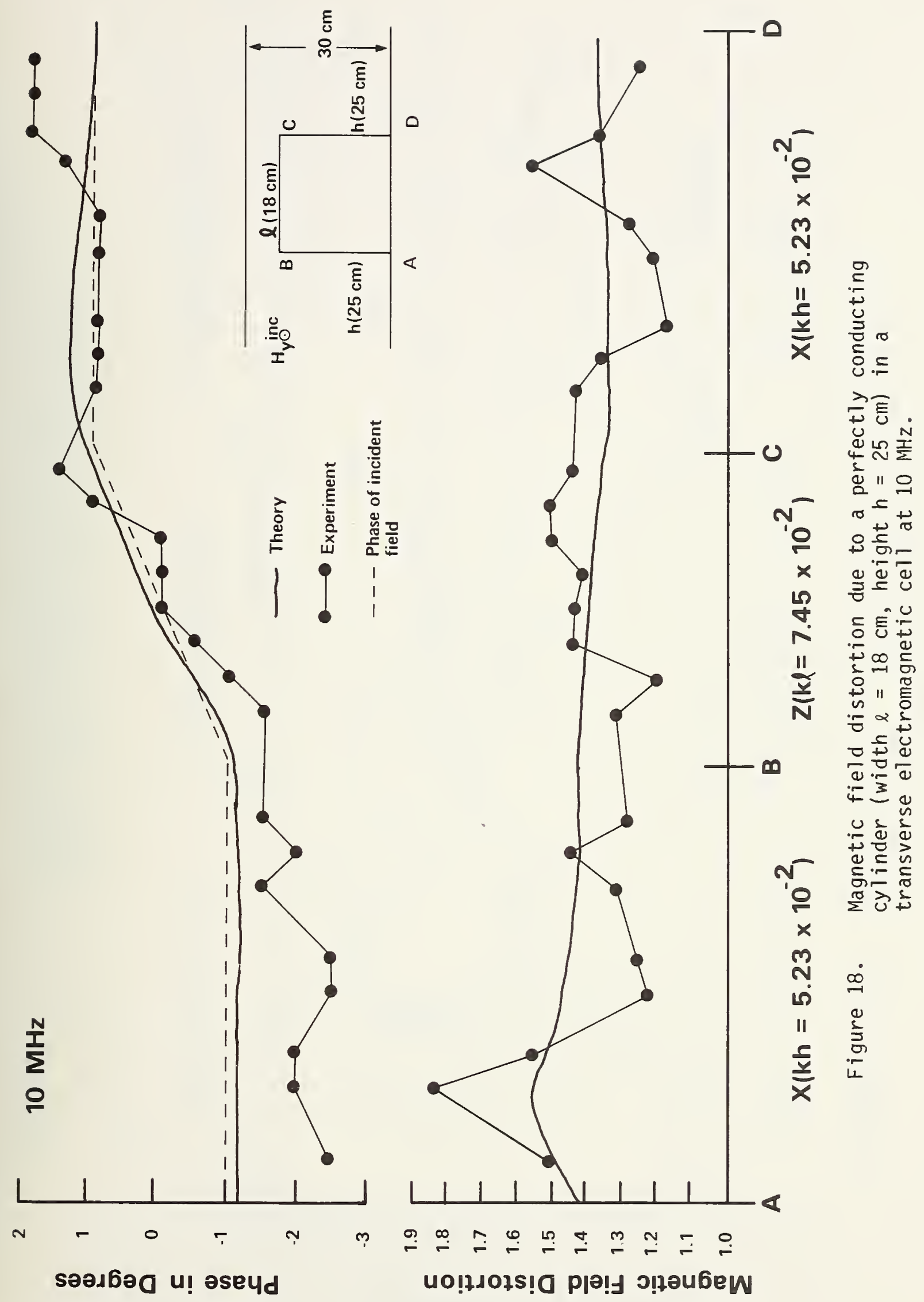




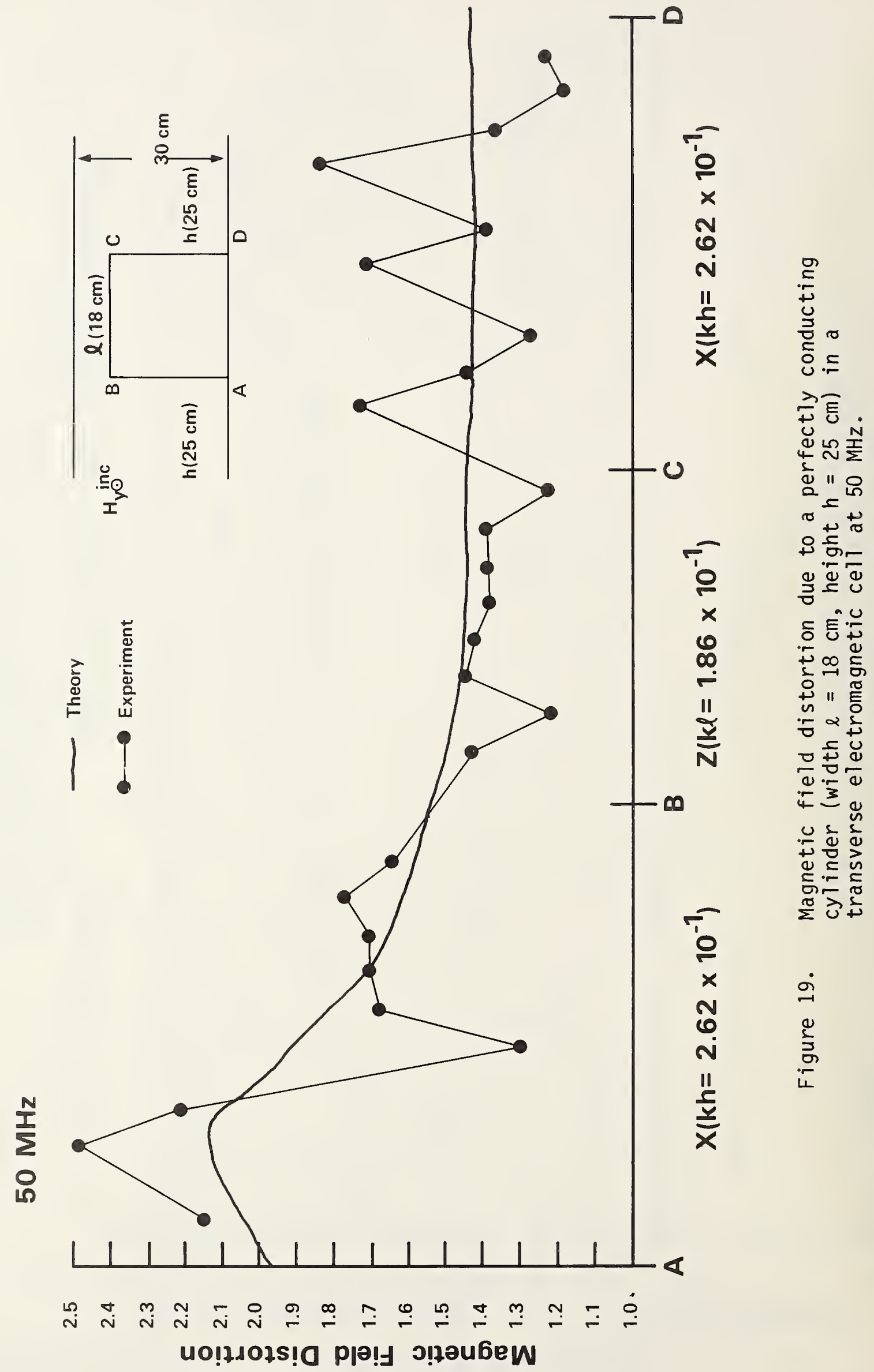




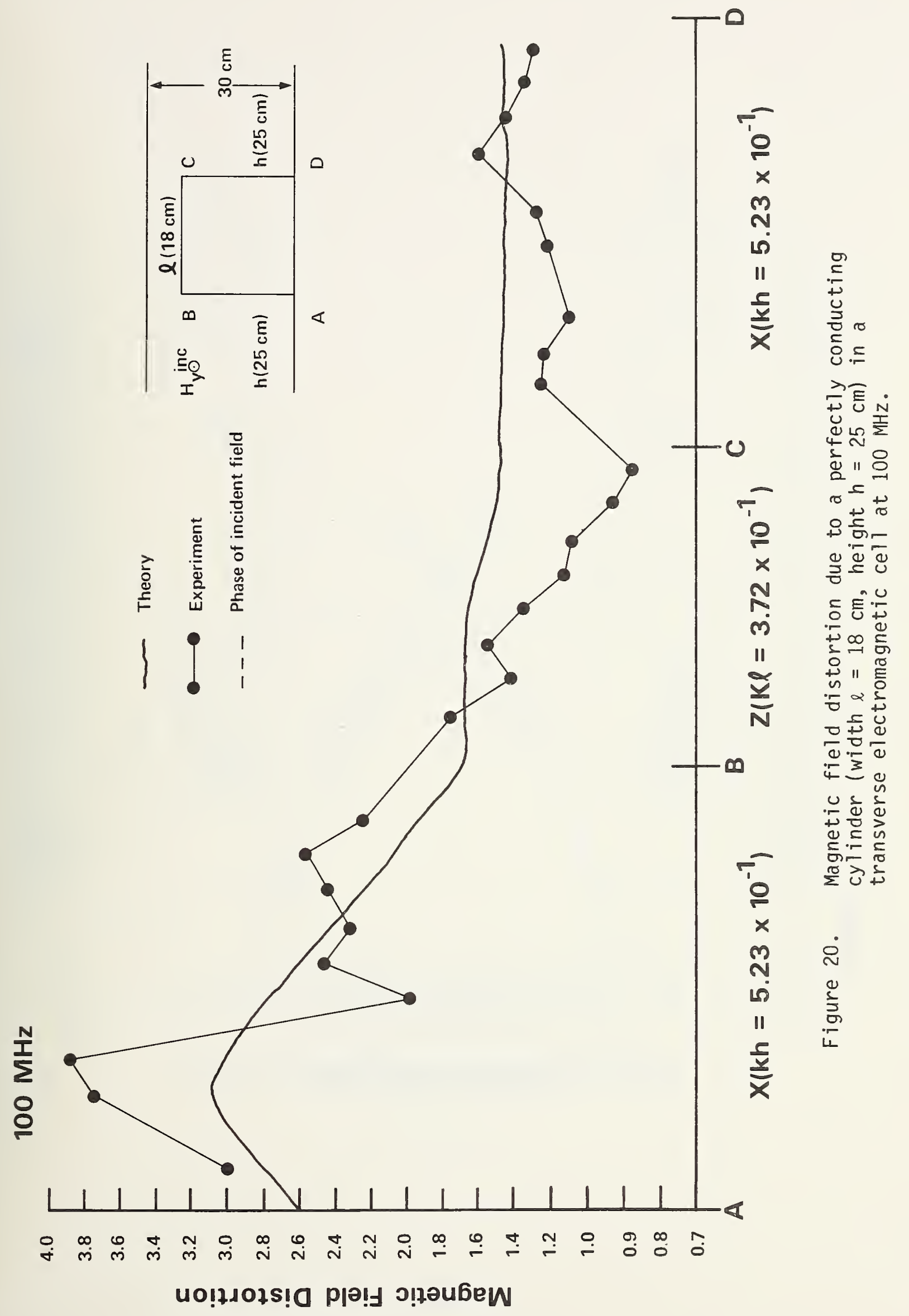




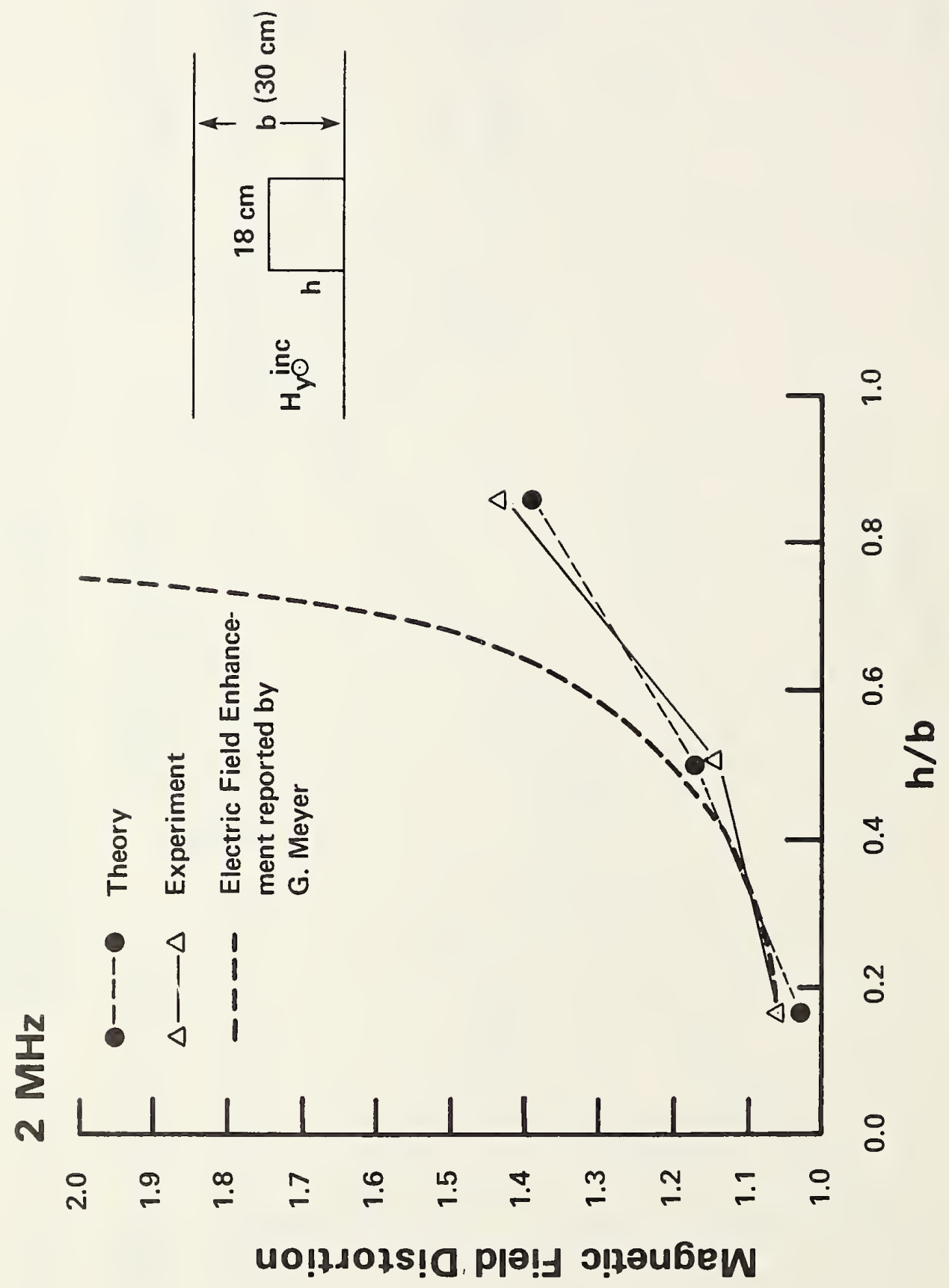

$\frac{\mathscr{L}}{1}$

4 등

둥

요오

定 워

$+0$

동

ธิ 可 U

万人

잉

†

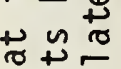

$-2$

ธั4

ㄴ.

어요

थ

둥

므옿

乎先出

芒害

政

‥

줄 중

$\dot{\text { ล }}$

ปั) 


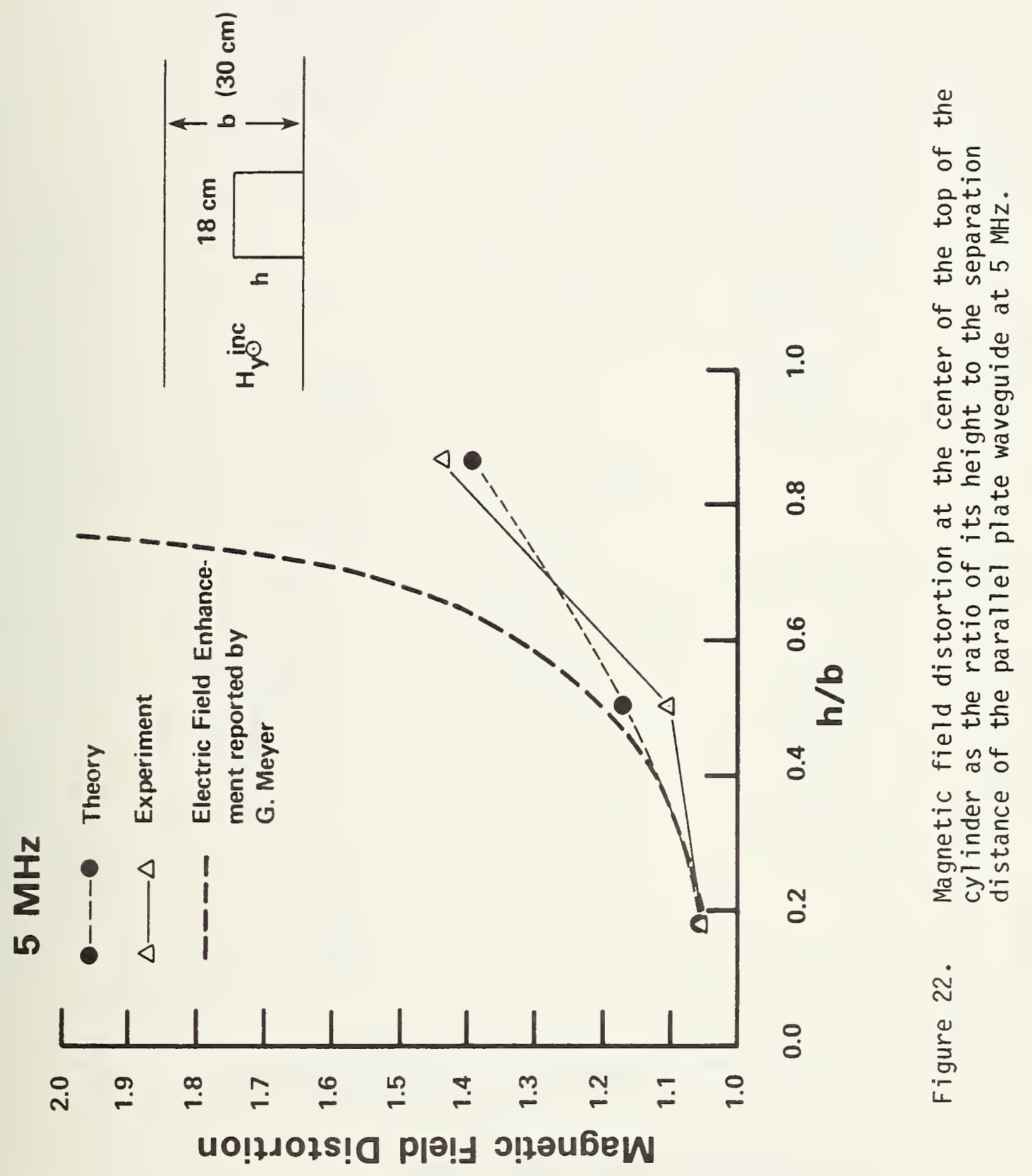




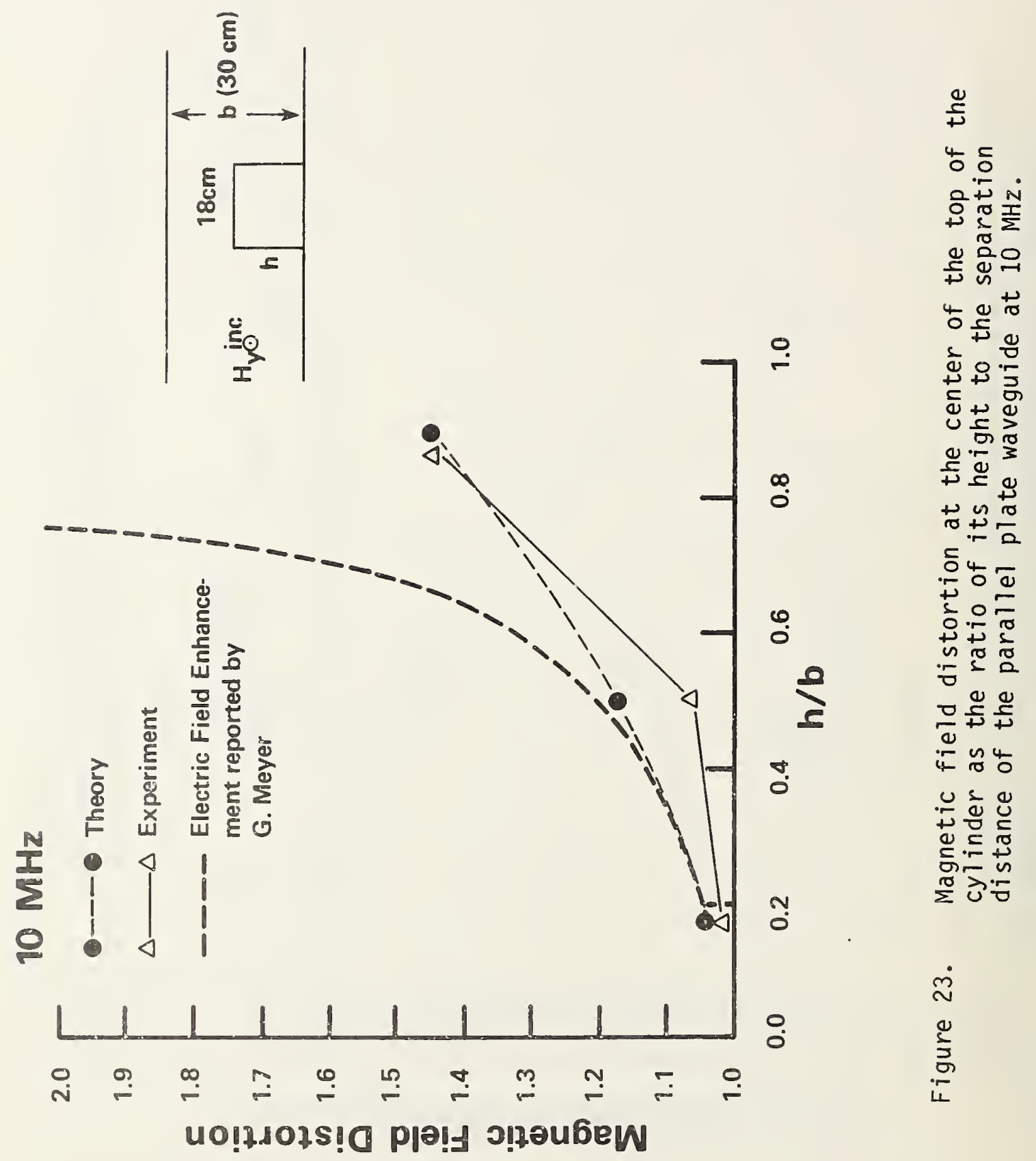




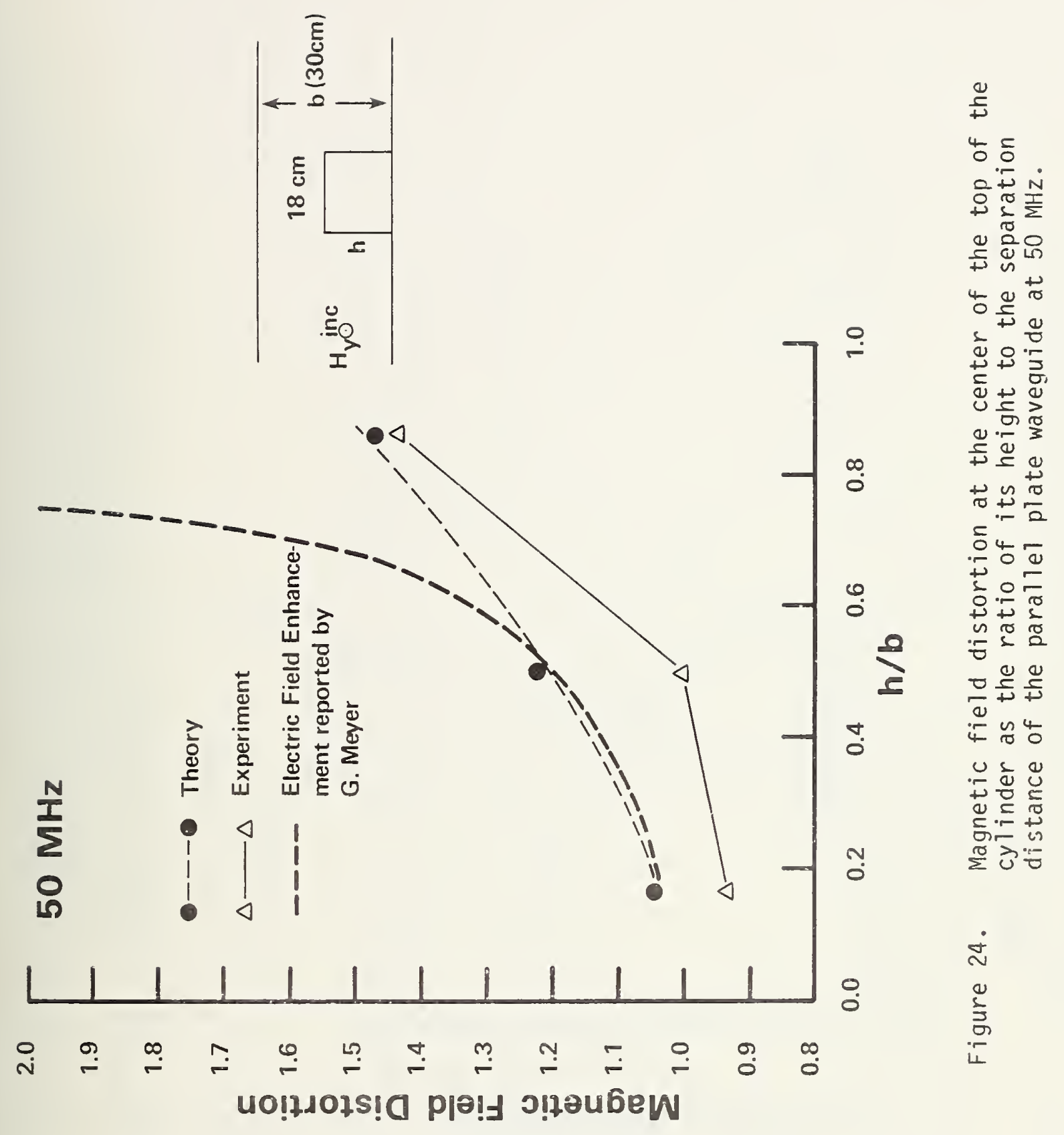




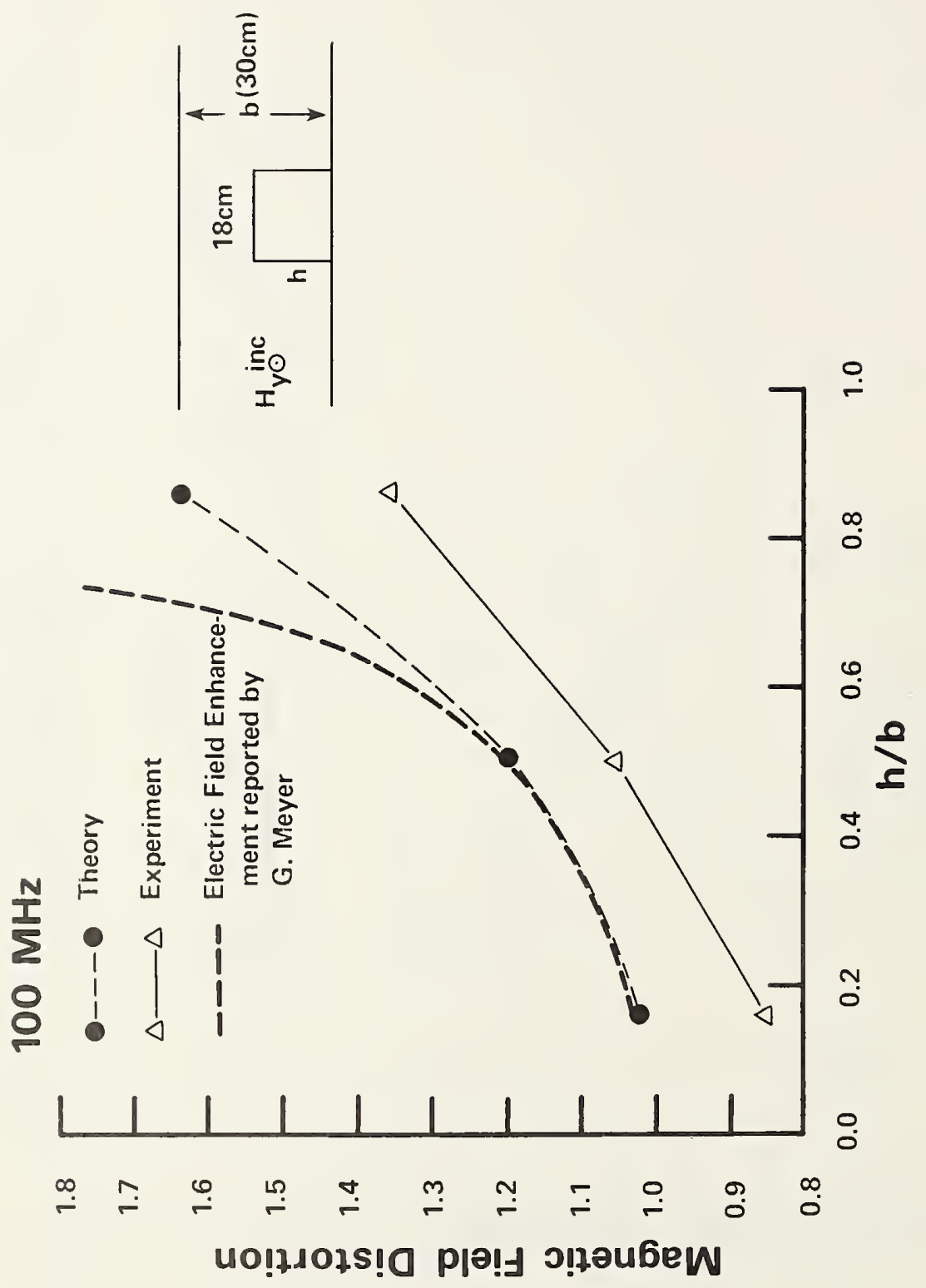

폰

4 등

응 壵至

ㅇㅇㅇ

䀡

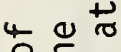

당

ฮั 동

可

U도

y 3

†

可

$\sigma$

둥ㅎ

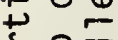

으웅

औ

- 5

드원

岳此

농

물

5.

줄 강

ณ่

站 


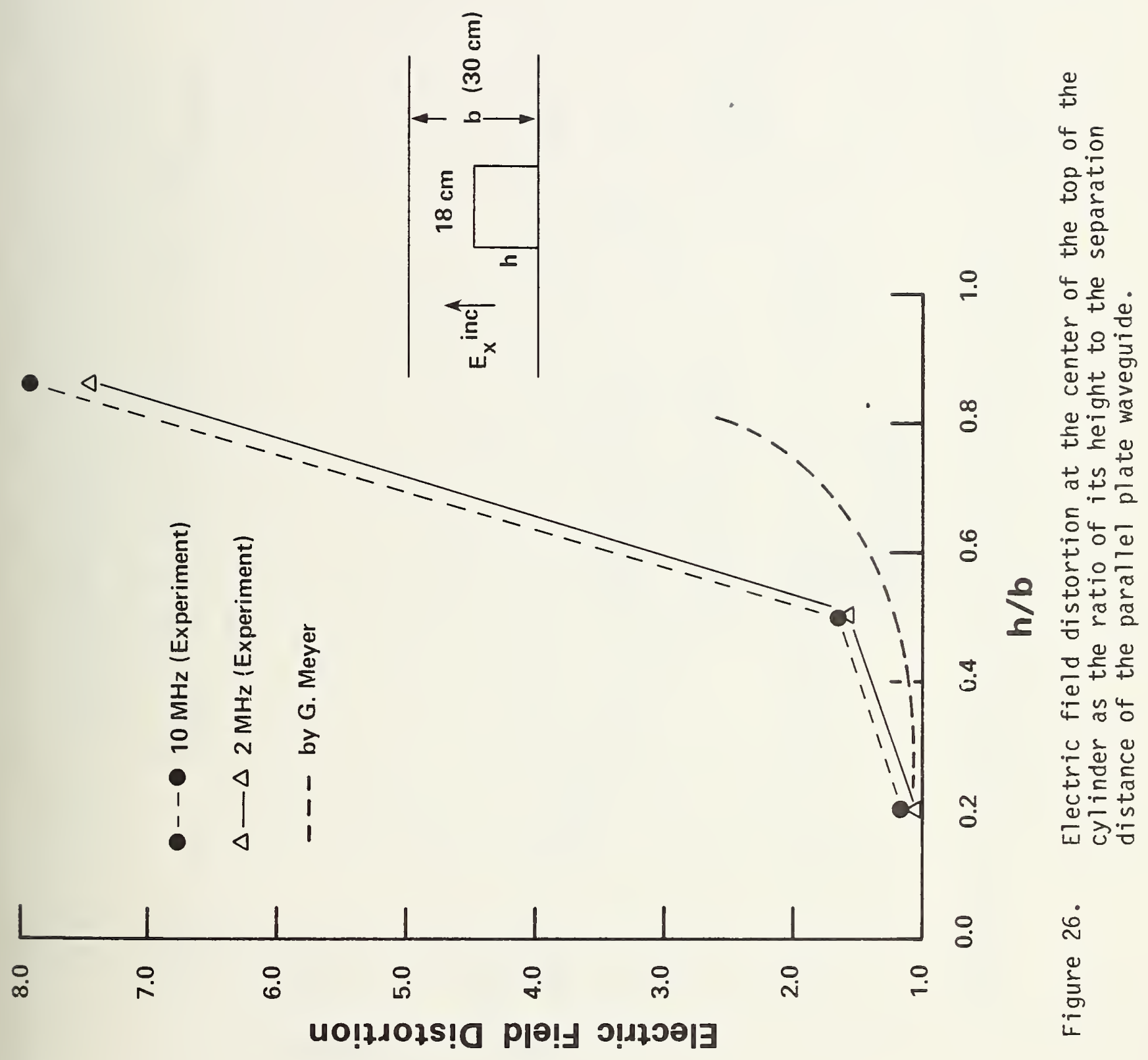




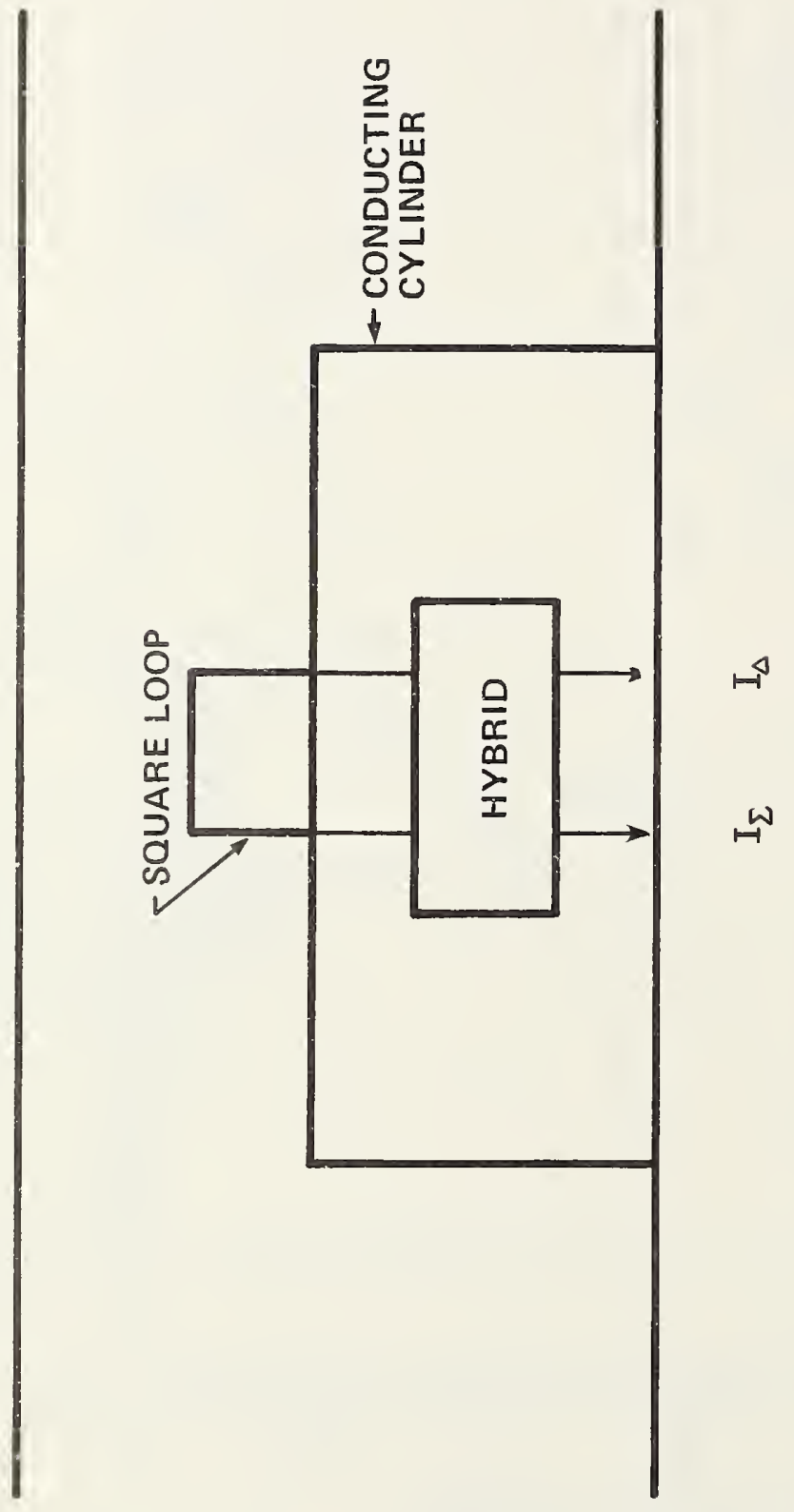

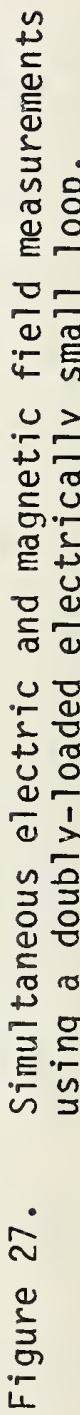




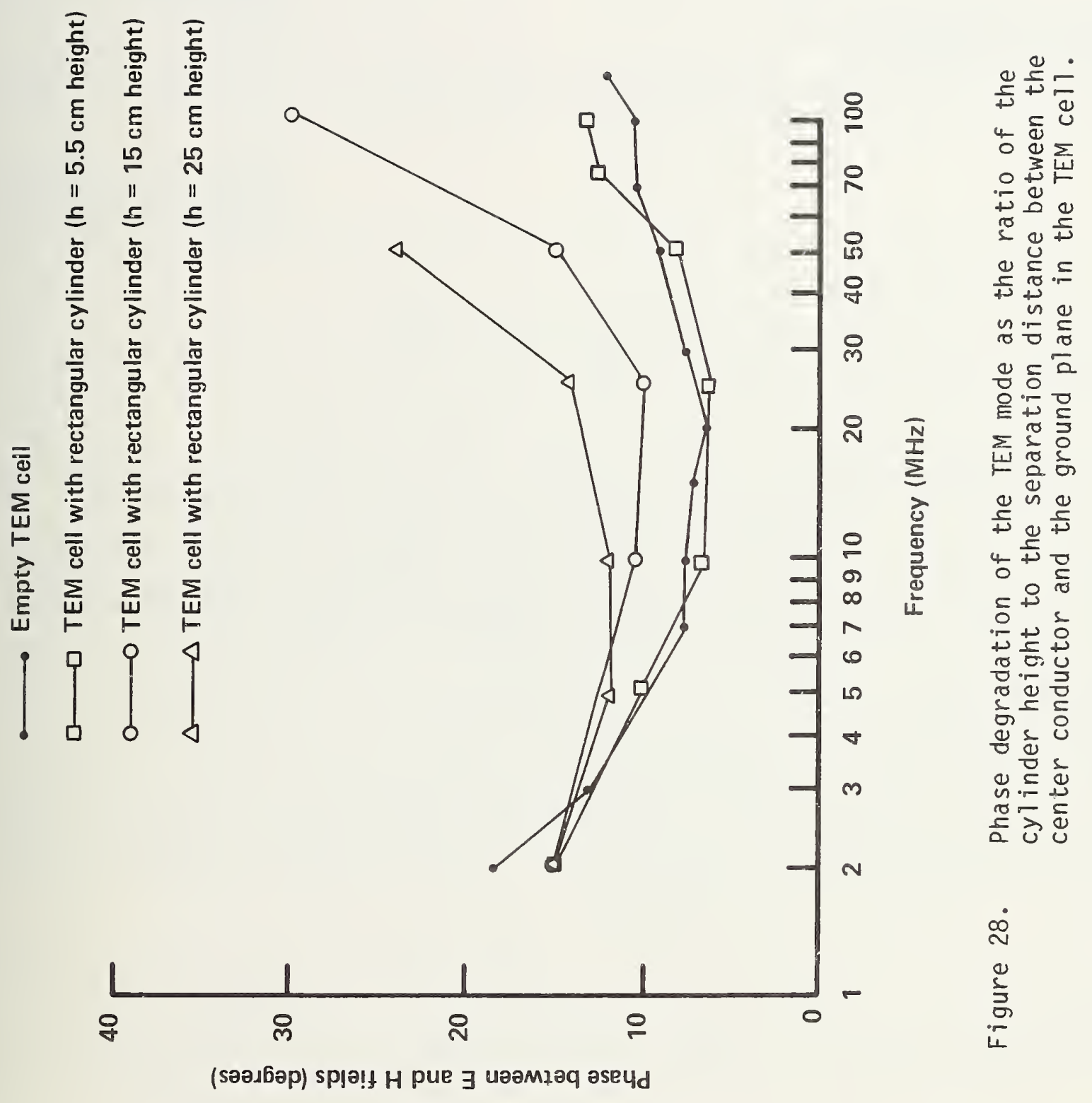


NBS.114A (REV. 0.78)

U.S. DEPT. OF COMM.

BIBLIOGRAPHIC DATA SHEET

1. PUBLICATION OR REPORT NO.

2. Gov't Accession 110,

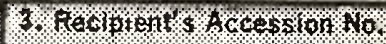

NBS TN-1028

4. TITLE AND SUBTITLE

Theoretical and Experimental Investigations of Electromagnetic Field Distortion Due to a Perfectly Conducting Rectangular Cylinder in a Transverse Electromagnetic Cell.

5. Publication Date

Apri 11981

7. AUTHOR(S)

Motohisa Kanda

9. PERFORMING ORGANIZATION NAME AND ADDRESS

10. Project/Task/Nork Unit No. 7233182

NATIONAL BUREAU OF STANDARDS

DEPARTMENT OF COMMERCE

WASHINGTON, DC 20234

12. SPONSORING ORGANIZATION NAME AND COMPLETE ADDRESS (Street, City, State, ZIP)

13. Type of Report \& Period Covered

14. Spansoring Agency Code

15. SUPPLEMENTARY NOTES

Document describes a computer program; SF-185, FIPS Software Summary, is attached.

16. ABSTRACT (A 200-word or less factual summary of most significant information. If document includes a significant bibliography or literature survey, mention it here.)

The study of electromagnetic compatibility (EMC), that is the electronic and biological effects due to electromagnetic (EM) radiation, and EM calibration require accurate EM measurement techniques for defining the EM interference (EM) characteristics. Thus, fully enclosed rectangular transverse electromagnetic (TEM) transmission lines with thin inner conductors are often used for generating standard known test fields. In all cases it is destrable that only the dominant TEM mode should propagate. In the EMC measurements, an object under test is placed inside of a TEM cell. The field from the TEM mode incident upon this scattering object is identical to that of a plane wave in a free space. However, the scattered field produced by the object in the TEM cell is different from the scattered field produced by the object in a free space, because of multiple reflections from the TEM cell walls, or equivalently, the mutual coupling between the object and the TEM cell. The purpose of this paper is to discuss the loading effects, i.e., the electromagnetic field distortion caused by an object under test in a TEM cell. In the theoretical analysis, the frequency domain integral equation for the magnetic field, or equivalently, the current density on the surface of a perfectly conducting cylinder in a parallel plate waveguide is solved by the method of moments to predict the degree of magnetic field distortion. The experimental investigations are performed by mounting a number of electrically small half loops on the surface of the perfectly conducting cylinder in a TEM cell. The loading effects in terms of magnetic field distortion are analyzed as the ratio of one of the object dimensions (height) to the separation distance between the inner conductor and the ground plane of the TEM cell. Also, the response of an electrically small loop to both the magnetic and electric components of the electromagnetic field is used to measure the phase relation between the magnetic and electric fields, which in turn can be used to determine the degree of degradation of the TEM mode due to the presence of the perfectly conducting cylinder. These theoretical and experimental results are compared with the available quasi electrostatic results.

17. KEY WORDS (six to twelve entries; alphabetical order; capitalize only the first letter of the first key word unless a proper name; separated by semicolons)

El ectromagnetic Compatibility (EMC); Green's function; integral equation; linear equation; method of moments; parallel plate waveguide; quasi electrostatic; TEM cell.
18. AVAILABILITY
Unlimited

For Official Distribution. Do Not Release to NTIS

XX Order From Sup. of Doc., U.S. Government Printing Office, Washington, DC 20402

Order From National Technical Information Service (NTIS), Springfield, VA. 22161

\begin{tabular}{|l|c|}
\hline $\begin{array}{l}\text { 19. SECURITY CLASS } \\
\text { (THIS REPORT) } \\
\text { UNCLASSIFIED }\end{array}$ & $\begin{array}{c}\text { 21. NO. OF } \\
\text { PRINTED PAGES }\end{array}$ \\
\hline $\begin{array}{l}\text { 20. SECURITY CLASS } \\
\text { (THIS PAGE) } \\
\text { UNCLASSIFIED }\end{array}$ & $\begin{array}{l}\text { 22. Price } \\
\$ 2.50\end{array}$ \\
\hline
\end{tabular}




\section{NBS TECHNICAL PUBLICATIONS}

\section{PERIODICALS}

JOURNAL OF RESEARCH-The Journal of Research of the National Bureau of Standards reports NBS research and development in those disciplines of the physical and engineering sciences in which the Bureau is active. These include physics, chemistry, engineering. mathematics, and computer sciences. Papers cover a broad range of subjects, with major emphasis on measurement methodology and the basic technology underlying standardization. Also included from time to time are survey articles on topics closely related to the Bureau's technical and scientific programs. As a special service to subscribers each issue contains complete citations to all recent Bureau publications in both NBS and nonNBS media. Issued six times a year. Annual subscription: domestic \$1.3: forcign $\$ 16.25$. Single copy, $\$ 3$ domestic: $\$ 3.75$ loreign.

NOTE; The Journal was formerly published in two sections: Section A "Physics and Chemistry" and Section B "Mathematical Sciences."

DIMENSIONS/NBS-This monthly magazine is published to inform scientists, engineers, business and industry leaders, teachers, students, and consumers of the latest advances in science and technology, with primary emphasis on work at NBS. The magazine highlights and reviews such issues as energy research, fire protection, building technology, metric conversion, pollution abatement, health and safety, and consumer product performance. In addition, it reports the results of Bureau programs in measurement standards and techniques, properties of matter and materials, engineering standards and services, instrumentation, and automatic data processing. Annual subscription: domestic \$11; foreign $\$ 13.75$.

\section{NONPERIODICALS}

Monographs-Major contributions to the technical literature on various subjects related to the Bureau's scientific and technical activities.

Handbooks-Recommended codes of engineering and industrial practice (including safety codes) developed in cosperation with interested industries, professional organizations, and regulatory bodies.

Special Publications-Include proceedings of conferences sponsored by NBS, NBS annual reports, and other special publications appropriate to this grouping such as wall charts, pocket cards, and bibliographies.

Applied Mathematics Series-Mathematical tables, manuals, and studies of special interest to physicists, engineers, chemists, biologists, mathematicians, computer programmers, and others engaged in scientific and technical work

National Standard Reference Data Series_Provides quantitative data on the physical and chemical properties of materials, compiled from the world's literature and critically evaluated. Developed under a worldwide program coordinated by NBS under the authority of the National Standard Data Act (Public Law 90-396).
NOTE: The principal publication outlet for the foregoing data is the Journal of Physical and Chemical Reference Data (JPCRD) published quarterly for NBS by the American Chemical Society (ACS) and the American Institute of Physics (AIP). Subscriptions, reprints, and supplements available from ACS, 1155 Sixteenth St, NW, Washington, DC 20056

Building Science Series-Disseminates technical information developed at the Bureau on building materials, components, systems, and whole structures. The series presents research results, test methods, and performance criteria related to the structural and environmental functions and the durability and safety characteristics of building elements and systems.

Technical Notes-Studies or reports which are complete in themselves but restrictive in their treatment of a subject. Analogous to monographs but not so comprehensive in scope or definitive in treatment of the subject area. Often serve as a vehicle for final reports of work performed at NBS under the sponsorship of other government agencies

Voluntary Product Standards-Developed under procedures published by the Department of Commerce in Part 10, Title 15, of the Code of Federal Regulations. The standards establish nationally recognized requirements for products, and provide all concerned interests with a basis for common understanding of the characteristics of the products. NBS administers this program as a supplement to the activities of the private sector standardizing organizations.

Consumer Information Series-Practical information, based on NBS research and experience, covering areas of interest to the consumer. Easily understandable language and illustrations provide useful background knowledge for shopping in today's technological marketplace.

Order the above NBS publications from: Superintendent of Documents, Government Printing Office, Washington, DC 20402

Order the following NBS publications-FIPS and NBSIR's-from the National Technical Information Services, Springfield, VA 22161.

Federal Information Processing Standards Publications (FIPS PUB)-Publications in this series collectively constitute the Federal Information Processing Standards Register. The Register serves as the official source of information in the Federal Government regarding standards issued by NBS pursuant to the Federal Property and Administrative Services Act of 1949 as amended, Public Law 89-306 (79 Stat. 1127), and as implemented by Executive Order 11717 (38 FR 12315, dated May 11, 1973) and Part 6 of Title 15 CFR (Code of Federal Regulations).

NBS Interagency Reports (NBSIR) - A special series of interim or final reports on work performed by NBS for outside sponsors (both government and non-government). In general, initial distribution is handled by the sponsor; public distribution is by the National Technical Information Services, Springfield, VA 22161 , in paper copy or microfiche form. 
U.S. DEPARTMENT OF COMMERCE

National Bureau of Standards

Washington, D.C. 20234

OFFICIAL BUSINESS

Penalty for Private Use, $\$ 300$
POSTAGE AND FEES PAID U.S. DEPARTMENT OF COMMERCE COM-215

SPECIAL FOURTH-CLASS RATE BOOK 